\title{
ADSA Foundation Scholar Award: Possibilities and Challenges of Exopolysaccharide-Producing Lactic Cultures in Dairy Foods
}

\author{
A. N. Hassan \\ Dairy Science Department, South Dakota State University, Brookings 57007-0647
}

\begin{abstract}
Exopolysaccharides (EPS) from lactic acid bacteria are a diverse group of polysaccharides exhibiting various functional properties. Two forms of EPS are produced by lactic acid bacteria: capsular and unattached. Capsular EPS does not cause ropiness nor does production of unattached EPS ensure ropiness. The functions of EPS in dairy products are not completely understood. This is for 2 main reasons: the major variations among exopolysaccharides even from the same group of microorganisms, which makes it difficult to apply information from one EPS to others, and the lack of availability of techniques with the ability to observe the microstructure and distribution of the highly hydrated EPS in fermented dairy products. The introduction of relatively new microscopic techniques such as confocal scanning laser microscopy and cryo-scanning electron microscopy made it possible to directly observe the distribution of fully hydrated EPS in dairy products. Recently, EPS produced by nonropy strains have drawn the attention of the dairy industry. This is because of the ability of some nonropy strains to produce large capsular and unattached EPS that would improve the texture of dairy products without causing the undesirable slippery mouthfeel produced by the ropy strains. Factors affecting functions of EPS are their molecular characteristics and ability to interact with milk proteins. Studying the interaction between EPS and milk proteins is complex because EPS are gradually produced during fermentation, unlike polysaccharides added directly to milk to stabilize the fermented product. The concentration and possibly molecular characteristics of EPS and protein characteristics such as charge and hydrophobicity change during fermentation. Consequently, the interaction of EPS with proteins might also change during fermentation. Exopolysaccharides provide functions that benefit reduced-fat cheeses. They bind water and increase the moisture in the nonfat
\end{abstract}

Received July 27, 2007.

Accepted December 7, 2007.

E-mail: Ashraf.Hassan@sdstate.edu portion, interfere with protein-protein interactions and reduce the rigidity of the protein network, and increase viscosity of the serum phase. This review discusses the production of capsular EPS and their role in structure formation in fermented milk, the mechanism of ropiness formation, and applications of EPS-producing cultures in reduced-fat cheeses.

Key words: exopolysaccharide, cheese, texture, microstructure

\section{INTRODUCTION}

Exo- (or extracellular) polysaccharides (EPS) are polysaccharides secreted outside the cell wall of the producing microorganism. Such polymers can remain attached to the cell in the form of capsules or be secreted as unattached materials. Some strains produce both forms of EPS and others produce only the unattached type; strains producing only the capsular type have not been confirmed (Hassan et al., 2003b). Ropiness is a term used to describe threads that can be drawn out from the surface of fermented milk by a needle or other means. The term "ropy" has been used to describe strains producing EPS or ropiness. Therefore, lactic cultures were classified into ropy and nonropy based on their ability to produce EPS. Recently, some nonropy strains of lactic acid bacteria (LAB) were found to produce significant amounts of EPS that could exceed those produced by ropy strains (van Marle and Zoon, 1995). Capsular EPS does not cause ropiness. Hassan et al. (2003b) classified LAB, based on the form of EPS produced, into the following groups: group I: capsule-forming ropy strains that produce capsules and unattached ropy EPS; group II: capsule-forming nonropy strains that produce capsules and possibly unattached EPS (not all unattached EPS produce ropiness); group III: noncapsule-forming ropy strains; and group IV: strains producing no or undetectable EPS. Figure 1 shows a classification of LAB based on the type of EPS produced. Exopolysaccharides produced by LAB are classified based on their sugar composition into homopolysaccharides and heteropolysaccharides. Homopolysaccharides contain only one sugar type, either D-glucopyranose or D-fructofuranose (Monsan et al., 2001), whereas hetero- 


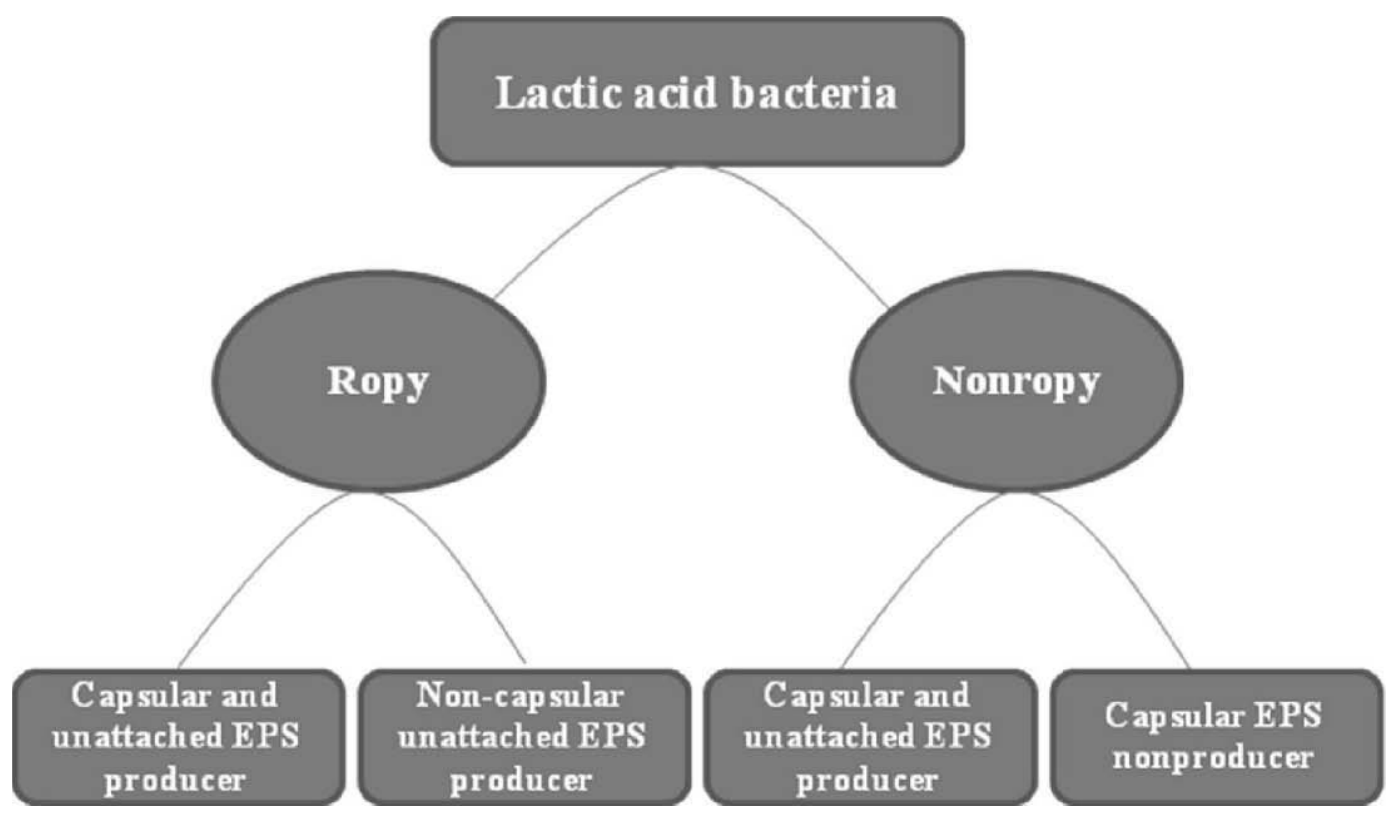

Figure 1. Classification of lactic acid bacteria based on the type of exopolysaccharide (EPS) produced. Strains producing capsular but not unattached EPS and noncapsule-forming nonropy strains producing unattached EPS have not been confirmed.

polysaccharides are composed of a backbone of 3 to 8 repeated subunits of monosaccharides, derivatives of monosaccharides, or substituted monosaccharides (De Vuyst et al., 2001). Most heteroexopolysaccharides from lactic acid bacteria contain D-glucose, D-galactose, and L-rhamnose.

Exopolysaccharide-producing lactic cultures have been used to modify the textural and functional properties of fermented dairy products (Hassan et al., 1996a,b; Ruas-Madiedo et al., 2002; Broadbent et al., 2003; Awad et al., 2005b; Hassan et al., 2005). The structure-function relationship of EPS has been the subject of many studies (Faber et al., 1998; Goh et al., 2005; Korakli and Vogel, 2006). Understanding this relationship would allow chemical, enzymatic, or genetic modification of the polysaccharide to obtain tailored characteristics in fermented dairy products (De Vuyst et al., 2001). This review will shed light on recent research results on EPS from LAB with emphasis on microscopic observations and applications in cheese.

\section{PRODUCTION OF CAPSULAR EPS BY LAB}

Lactic acid bacteria produce 2 forms of EPS, capsular and unattached. Production of unattached EPS has been extensively reviewed (Ricciardi and Clementi, 2000; Degeest et al., 2001; Ruas-Madiedo et al., 2002; Welman and Maddox, 2003; Ruas-Madiedo and de los Reyes-Gavilán, 2005), whereas limited information is available on production of capsular EPS by LAB.
Accurate observation of bacterial capsules by conventional techniques such as light and electron microscopy is difficult because of the highly hydrated state of the capsules. In addition, capsule size determined by the traditional india ink technique depends on the size of the ink particles, which varies from batch to batch. Hassan et al. (1995a) developed a confocal scanning laser microscopy (CSLM) technique to observe capsules of lactic cultures grown in milk in their fully hydrated state. They found that both bacterial cells and casein micelles reflect laser light. Bacterial capsules appear as black, nonreflecting zones. Capsule size and production are strain dependent (Hassan et al., 1995a). Size of the capsule (including bacterial cells) ranged from 1.5 to 5 $\mu \mathrm{m}$ (Figure 2). Some nonropy strains produced capsules almost double the size of that produced by highly ropy strains (Hassan et al., 1995a).

Factors affecting EPS production have been extensively studied (De Vuyst et al., 1998; Gamar-Nourani et al., 1998; Grobben et al., 2000; Gorret et al., 2001; Zisu and Shah, 2003). Results suggest that EPS-positive strains produce some EPS under any growth condition. However, the amount and in some cases the structure of the EPS depend on the growth medium and conditions ( $\mathrm{pH}$, temperature, aeration, and so on). Milk is the preferred medium for capsule production by nonropy LAB (Hassan et al., 1995a). Factors affecting production of capsular EPS by LAB were studied by Hassan et al. (2001c). They found that the size of the capsule produced by a nonropy strain of Streptococcus ther- 


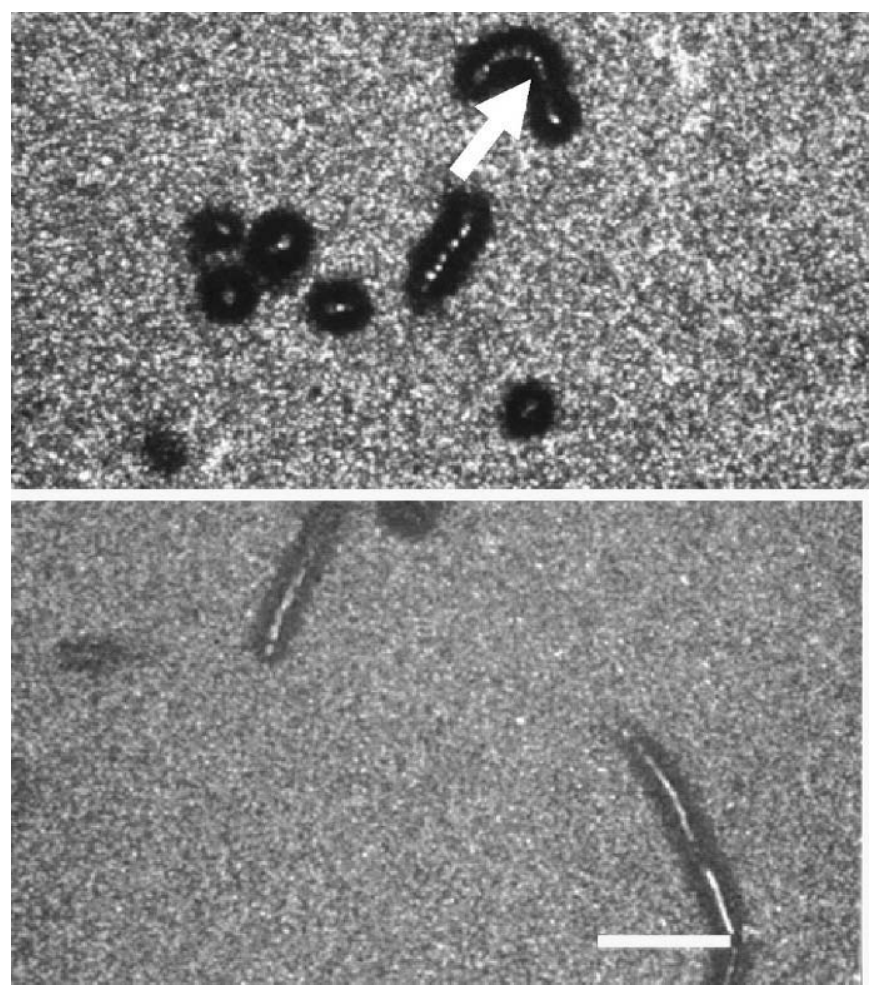

Figure 2. Photomicrographs of capsule-forming strains of Streptococcus thermophilus S3855S (top) and Lactobacillus delbrueckii ssp. bulgaricus RR (bottom). Arrow points to bacterial capsule; bar $=10$ $\mu \mathrm{m}$. Source: Hassan et al. (1995a).

mophilus in milk was almost twice that produced in Elliker's broth (Table 1). Increasing the lactose level of Elliker's broth to 5\% and addition of whey protein concentrate produced a similar capsule size to that formed in milk. Unlike the nonropy strains, the ropy strain they tested (Lactobacillus delbrueckii ssp. bulgaricus $\mathrm{RR}$ ) produced the same capsule size in any growth medium (Table 1). Hassan et al. (2001c) also found that some strains of Strep. thermophilus produced capsules when grown on galactose as the sole sugar (Table 1), indicating that Strep. thermophilus can use galactose to form capsules. Mozzi et al. (1995) found that a strain of Lactobacillus casei produced larger capsules in the presence of galactose. Although Strep. thermophilus does not ferment galactose, it uses the galactose moiety of lactose via the Leloir pathway to form EPS precursors (Levander and Rådström, 2001). The use of galactose for the production of EPS could be of technological significance by inhibiting growth of undesirable heterofermentative LAB and producing lowbrowning Mozzarella cheese by reduced levels of reducing sugars (Hassan et al., 2001c). Some strains of LAB lost their ability to produce capsules in nonsupporting media (Hassan et al., 2001c). Strains not producing capsules in milk do not seem to form capsules in any other growth medium (Hassan et al., 2001c).

\section{EFFECT OF EPS PRODUCTION ON STRUCTURE FORMATION OF FERMENTED MILK}

Milk gelation is an important step in making cheese and fermented milk. During gelation, casein micelles aggregate and form a 3-dimensional network that, under the microscope, looks like a sponge trapping milk serum and fat. Factors affecting the structure and microstructure of the coagulum of fermented milk determine the final product characteristics. Milk gelation is initiated below pH 5.5 (Hassan et al., 1995b). As the $\mathrm{pH}$ drops from 6.6 to 5.5, some strains of LAB produce sufficient amounts of EPS to affect structure formation (Hassan et al., 1995b). Such strains produce EPS in the form of unattached slime or large capsules. The EPS can affect formation of casein gel structure by acting as filler. Therefore, the effect of EPS on protein matrix and structure formation depends on their concentration, interactions with the protein, and molecular and rheological characteristics. Studying the relationship between EPS and casein micelles is rather complex because, unlike other polysaccharides added directly to milk to stabilize the fermented product, EPS are gradually produced during fermentation. Therefore, their concentration and perhaps their molecular characteristics change during fermentation. Consequently, their interactions with proteins might also change during fermentation. In addition, the interaction of EPS with milk proteins is influenced by the protein charge, hydrophobicity, and other characteristics that also change during fermentation. Hassan et al. (1995b) used CSLM to observe coagulation of milk fermented with EPS-positive cultures in real time. They used the reflectance mode of the microscope to observe casein micelles. Exopolysaccharides do not reflect laser light and appear as black zones that cannot be distinguished from milk serum. Bacterial capsules, because of their distinct structure and location relative to bacterial cells, can be readily observed. The effect of large capsules produced by a strain of Strep. thermophilus on formation of casein gel structure can be seen in Figure 3. From pH 6.4 to 5.5 , no change in the size of the capsule or casein micelles was seen. At $\mathrm{pH}$ 5.5, casein micelles were much coarser in milk fermented with the capsule-producing culture than in the control milk. A sudden change in fermented milk at $\mathrm{pH} 5.35$ made bacterial motion no longer visible; this indicated the initiation of gelation. At this point, casein micelles contracted away from cells and their capsules, which acted as nuclei for the formation of large pores containing bacterial cells, capsules, and milk serum. The contraction of the protein aggre- 
Table 1. Capsule diameter $(\mu \mathrm{m})$ produced by lactic acid bacteria in various growth media (adapted from Hassan et al., 2001c $)^{1}$

\begin{tabular}{|c|c|c|c|c|}
\hline \multirow[b]{2}{*}{ Medium } & \multicolumn{4}{|c|}{ Lactic acid bacteria $^{2}$} \\
\hline & $\mathrm{S} 2$ & S3 & S3855 & Lb RR \\
\hline Elliker & $2.25^{\mathrm{a}}$ & ND & $2.55^{\mathrm{c}}$ & $3.0^{\mathrm{a}}$ \\
\hline $\begin{array}{l}\text { Modined Elliker } \\
\text { Lactose }\end{array}$ & ND & ND & $3.57^{\mathrm{b}}$ & $30^{\mathrm{a}}$ \\
\hline Sucrose & ND & ND & $2.8^{\mathrm{c}}$ & NG \\
\hline Glucose & ND & ND & $2.0^{\mathrm{d}}$ & $3.0^{\mathrm{a}}$ \\
\hline Glucose + galactose & ND & ND & $2.5^{\mathrm{c}}$ & $3.0^{\mathrm{a}}$ \\
\hline Galactose & ND & ND & $2.8^{\mathrm{c}}$ & NG \\
\hline \multicolumn{5}{|l|}{ Modified Elliker ${ }^{4}$} \\
\hline Whey protein concentrate & - & ND & $3.5^{\mathrm{b}}$ & - \\
\hline Whey protein concentrate + lactose & - & ND & $4.5^{\mathrm{a}}$ & - \\
\hline Milk $11 \%$ solids & $2.2^{\mathrm{a}}$ & ND & $5.0^{\mathrm{a}}$ & $3.0^{\mathrm{a}}$ \\
\hline
\end{tabular}

gates led to formation of large clusters of protein connected via strands. Aggregated clusters in the milk fermented with the capsule-forming culture were much larger than those in the control milk (containing no EPS) at high $\mathrm{pH}$ values (5.25 to 5; Figure 3 ). Less difference in the size of the aggregates was observed at lower $\mathrm{pH}$ values (4.4 to 4.2 ) between milk fermented with capsule-forming and nonforming cultures, which indicated more extensive rearrangement in the former fermented milk after the initiation of gelation (Figure 4). The effect of capsule-forming nonropy cultures on structure formation was also monitored using low-shear dynamic measurements (Hassan et al., 2002a). The gelation point occurred at a higher $\mathrm{pH}$ value in milk fermented with the capsule-forming nonropy culture (gelation at $\mathrm{pH}$ 5.5) than in milk fermented with either a ropy or an EPS-nonproducing culture (gelation at 5.3 to 5.4). Dynamic rheological measurements indicated that gelation initiated at a $\mathrm{pH}$ value higher than that required to cause a dramatic change in the motion of bacterial cells as observed by CSLM. It actually happened when slower movement of bacterial cells was observed ( $\mathrm{pH}$ 5.5). Early gelation in milk fermented with capsule-forming nonropy cultures might be due to the volume exclusion effect of bacterial capsules or the interaction of the capsule with casein micelles. However, the contraction of casein aggregates away from capsules during fermentation as observed by CSLM indicates a lack of interaction between the capsules and milk proteins. It is unclear why the capsular but not the ropy EPS affected the gelation point of fermented milk (Hassan et al., 2002a).

If the ropy culture used in making fermented milk was L. delbrueckii ssp. bulgaricus and not Strep. ther- mophilus, the amount of EPS produced in milk before structure formation might not be sufficient to affect the gelation point, because most of the growth and associated production of EPS occur at $\mathrm{pH}$ values below 5.5. It seems that a large capsule, a large amount of EPS, or interaction of EPS with the casein micelles is needed for EPS to influence the gelation point. As the $\mathrm{pH}$ dropped below 5 , fewer differences were seen in the viscoelastic moduli between milk fermented with the capsule-forming culture and control milk containing no EPS (Table 2). This is consistent with the CSLM observations that showed fewer microstructural differences between the 2 milks as the $\mathrm{pH}$ dropped below 5. Early gelation allowed more rearrangement and slower development in the structure of milk fermented with the capsule-forming nonropy culture than in control milk. A peak in $\tan \delta$ (loss tangent) was observed in fermented milk soon after the gelation point (Hassan et al., 2002a). This peak occurred at a higher $\mathrm{pH}$ value in milk fermented with the capsule-forming nonropy culture than in control milk. The value of $\tan \delta$ at its maximum was greater in milk fermented with the ropy culture than in that fermented with the capsule-forming nonropy culture, because of the presence of a greater viscous component in the former milk (Hassan et al., 2002a).

\section{FUNCTIONS OF EPS IN FERMENTED MILKS}

Functions of EPS in yogurt are not completely understood. This is due, in part, to the unavailability of a suitable microscopic technique. Conventional scanning electron microscopy shows EPS as thin filaments attached to a protein network and to bacterial cells (Figure 5). These fine filaments are artifacts arising 

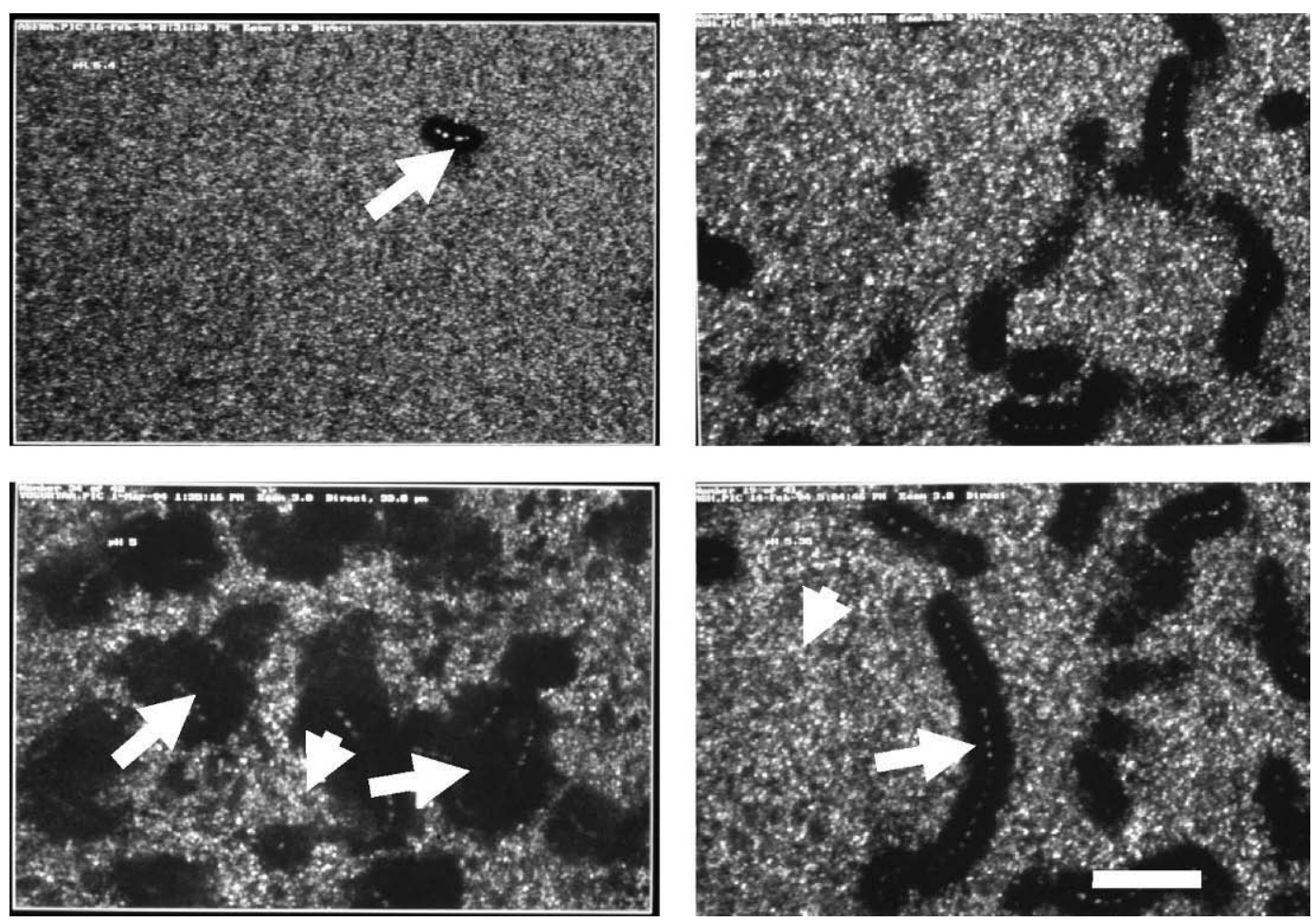

Figure 3. Photomicrographs of microstructure development in yogurt made with encapsulated lactic cultures obtained by using confocal scanning laser microscopy in reflectance mode. Top left: $\mathrm{pH}=6.4$, top right: $\mathrm{pH}=5.40$, bottom right: $\mathrm{pH}=5.35$, and bottom left: $\mathrm{pH}=5.0$. Long arrows indicate pores occupied by bacterial cells and their capsule; short arrows indicate protein aggregates; bar = $10 \mu \mathrm{m}$. Source: Hassan et al. (1995b).

during sample preparation. With CSLM, EPS and the protein network in yogurt appeared to be segregated, with EPS found in the serum phase (Figure 6). A direct interaction of EPS and the protein network was not confirmed due to the relatively limited resolution of the CSLM. In yogurt made with a highly ropy strain, larger amounts and greater masses of EPS than those in the moderately ropy yogurt were observed (Figure 6). Such EPS masses prevented the formation of a well-defined protein network. Stirring breaks the protein network, allowing more EPS-EPS interactions (Figure 6). The amount and type of EPS determine the level of EPSEPS or EPS-protein interactions that are responsible for the formation of long strands (ropiness; Hassan et al., 2002b; Tamime et al., 2007). This explains why ropiness increases upon stirring. Stirring yogurt before testing its ropiness is thus needed to facilitate such interactions. Segregation of EPS and protein in yogurt produces a more densely aggregated protein network than that in the EPS-negative yogurt (Hassan et al., 1995b, 2002b, 2003b). Exopolysaccharides decrease interactions between protein aggregates, leading to lower viscoelastic moduli, yield stress, and firmness (Hassan et al., 1996a,b, 2001a). Reduction in the rigidity of the protein network caused by EPS is expected to induce syneresis. Folkenberg et al. (2006) found that spontaneous syneresis was negatively correlated with gel firmness and positively correlated with ropiness and mouthfeel thickness. However, studies that showed reduced syneresis in the EPS-positive yogurt used mostly gravity or centrifugal forces during measurements (Cerning, 1990; Hassan et al., 1996b; Marshall and Rawson, 1999). Exopolysaccharides increase the water-holding capacity of yogurt (Hassan et al., 1996b). It seems that the open structure of yogurt produced by the EPS-positive strains increases syneresis, while the ability of EPS to bind or trap milk serum is responsible for the high water-holding capacity of the final fermented product. Polymer-like behavior of the serum phase in yogurt containing EPS increases the consistency index and yogurt viscosity (Hassan et al., 2003b).

Because of the high resolution of scanning electron microscopy, cryo-scanning electron microscopy images provided evidence of interactions between the EPS and protein network in yogurt (Figure 7). In addition, details of microstructure of the masses of EPS could also be observed (Figure 8). Exopolysaccharides produced by a moderately ropy strain of Strep. thermophilus formed a well-defined porous network. However, a highly ropy type of EPS had a dense entangled appear- 

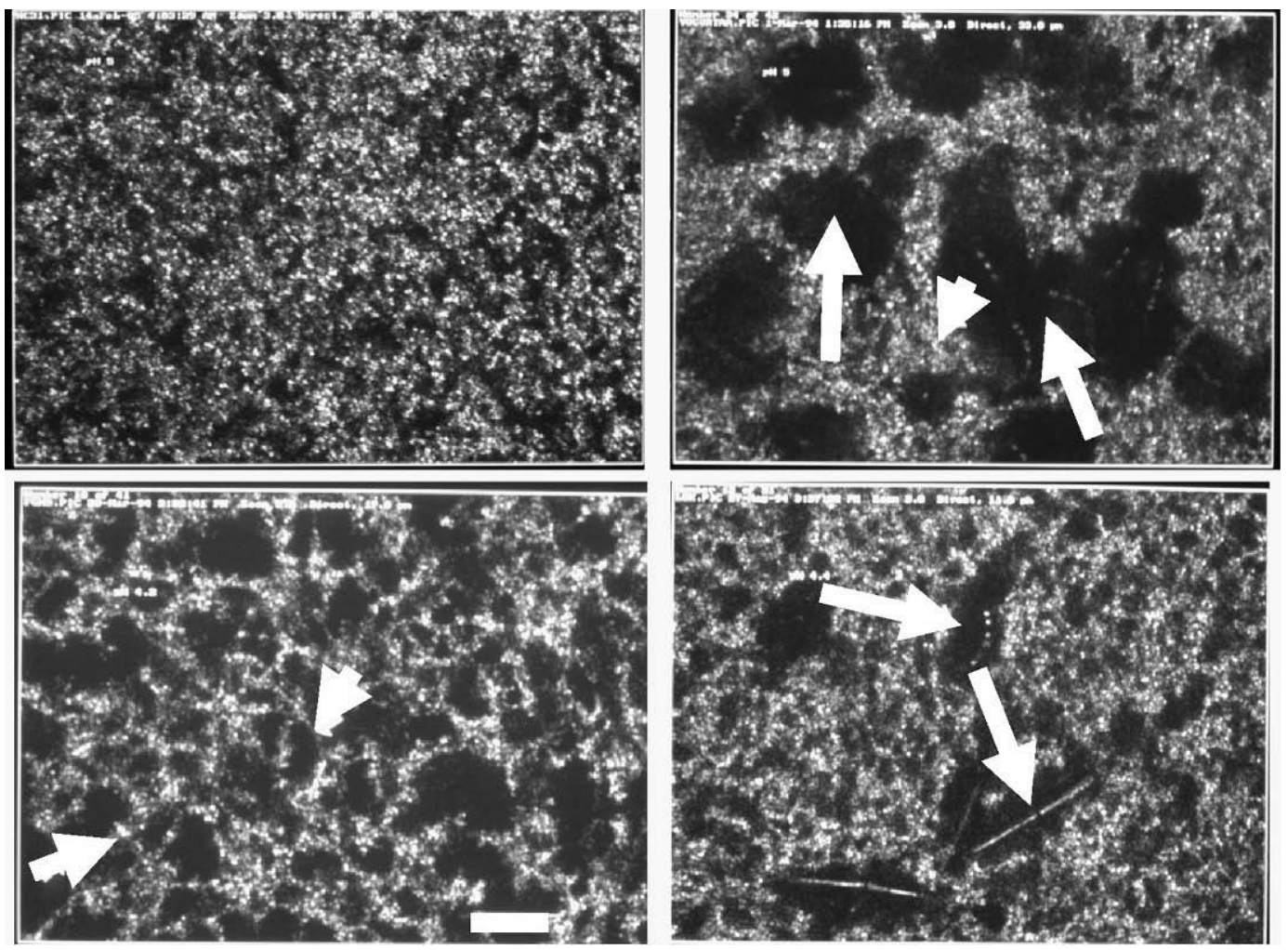

Figure 4. Optical sections of yogurt made using capsule-nonforming (left) and capsule-forming (right) lactic cultures at $\mathrm{pH} 5.0$ (top), $\mathrm{pH}$ 4.2 (bottom left), and 4.4 (bottom right). Long arrows indicate pores occupied by bacterial cells and their capsule; short arrows indicate protein aggregates; bar $=10 \mu \mathrm{m}$. Source: Hassan et al. (1995b).

ance with randomly distributed and relatively thick strands (Hassan et al., 2003a). The microstructure of EPS might be affected by molecular characteristics such as charge, hydrophobicity, degree of branching, and type of linkages.

\section{EFFECT OF EPS ON THE PHYSICAL PROPERTIES OF FERMENTED MILK}

\section{Capsular EPS}

Only a few studies examined the role of bacterial capsules on the physical properties of fermented milk
(Hassan et al., 1996a,b, 2002a; Amatayakul et al., 2006). Most published work compared ropy cultures with nonropy ones. However, in most cases, the nonropy cultures were not tested for encapsulation. In addition, when capsule-forming nonropy strains are used, it is difficult to ensure that such strains do not produce some unattached EPS that could contribute to product characteristics. This makes it very difficult to study the role of bacterial capsules on the physical properties of fermented dairy products. Hassan et al. (1996a,b) found that capsule-forming nonropy cultures improved the textural and rheological properties of fermented milk.

Table 2. Least squares means for the complex modulus $\left(\mathrm{G}^{*}\right)$ at selected $\mathrm{pH}$ values for acidified milk prepared with different strains (from Hassan et al., 2002a)

\begin{tabular}{lcccccccc}
\hline & \multicolumn{7}{c}{$\mathrm{pH}$} \\
\cline { 2 - 8 } Sample $^{1}$ & 5.3 & 5.1 & 5.0 & 4.9 & 4.8 & 4.7 & 4.6 & 4.5 \\
\hline CNR & $46.5^{\mathrm{b}}$ & $67.6^{\mathrm{a}}$ & $106.9^{\mathrm{b}}$ & $150.6^{\mathrm{b}}$ & $193.2^{\mathrm{b}}$ & $242.4^{\mathrm{b}}$ & $283.9^{\mathrm{a}}$ & $304.7^{\mathrm{a}}$ \\
NCNR & $4.2^{\mathrm{a}}$ & $39.7^{\mathrm{a}}$ & $55.15^{\mathrm{a}}$ & $72.1^{\mathrm{a}}$ & $101.2^{\mathrm{a}}$ & $147.9^{\mathrm{a}}$ & $188.2^{\mathrm{a}}$ & $243.3^{\mathrm{a}}$ \\
R & $9.2^{\mathrm{a}}$ & $33.9^{\mathrm{a}}$ & $46.8^{\mathrm{a}}$ & $61.2^{\mathrm{a}}$ & $98.3^{\mathrm{a}}$ & $144^{\mathrm{a}}$ & $174.7^{\mathrm{a}}$ & $230.4^{\mathrm{a}}$ \\
\hline
\end{tabular}

${ }^{\mathrm{a}, \mathrm{b}}$ Values within the same column followed by different superscript letters are significantly different $(P$ $<0.05)$.

${ }^{1} \mathrm{CNR}=$ milk fermented with a capsule-forming nonropy culture; NCNR = milk fermented with a noncapsule-forming nonropy culture; $\mathrm{R}=$ milk fermented with a ropy culture. 


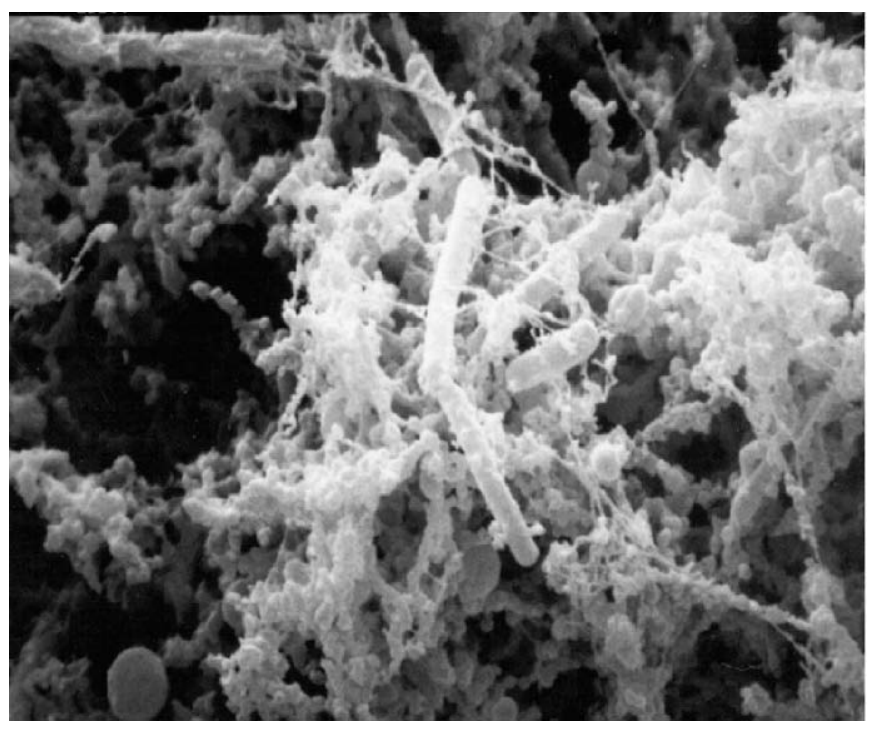

Figure 5. Conventional scanning electron microscopy image of milk fermented with an exopolysaccharide (EPS)-producing culture. Fine filaments indicate dehydrated EPS. Source: Anne Skriver, Chr. Hansen, Denmark.

They studied the effect of several strains producing capsule sizes ranging from 2 to $5 \mu \mathrm{m}$. A strain forming 5 - $\mu \mathrm{m}$ capsules produced slight ropiness only in the presence of $L b$. delbrueckii ssp. bulgaricus (A. N. Hassan, unpublished data). This could be because the capsule- forming nonropy strain produced small amounts of unattached EPS that increased in the presence of $L$. delbrueckii ssp. bulgaricus due to the availability of proteolysis products produced by Lactobacillus. Another possibility is that the capsule-forming nonropy strain produced unattached "ropy" EPS only in the presence of Lactobacillus. Therefore, the role of capsular EPS on the physical properties of yogurt should be cautiously interpreted. Bacterial capsules cannot be penetrated by large casein micelles. Therefore, their presence disrupts the continuity of the protein network and decreases protein-protein interactions. Void spaces around some bacterial cells that initiate with bacterial capsules (Hassan et al., 1995b, 1996a,b) affect the integrity and hardness of the milk coagulum (Hassan et al., 1996a,b). Such capsules act as nuclei for the formation of large pores (Figure 9). Therefore, capsule-positive yogurt contained large pores at relatively high $\mathrm{pH}$ values (5.1 to 4.8; Figure 4). Yogurt made with strains producing large capsules usually shows spontaneous syneresis, and a whey layer is formed on the surface of the yogurt during fermentation. This whey layer might be absorbed during cooling. Amatayakul et al. (2006) found that syneresis determined by the siphon method was reduced in yogurt made with a capsule-forming culture. Hassan et al. (1996a,b) compared the rheological and textural characteristics of milk fermented with capsuleforming and nonforming yogurt cultures. Capsule-
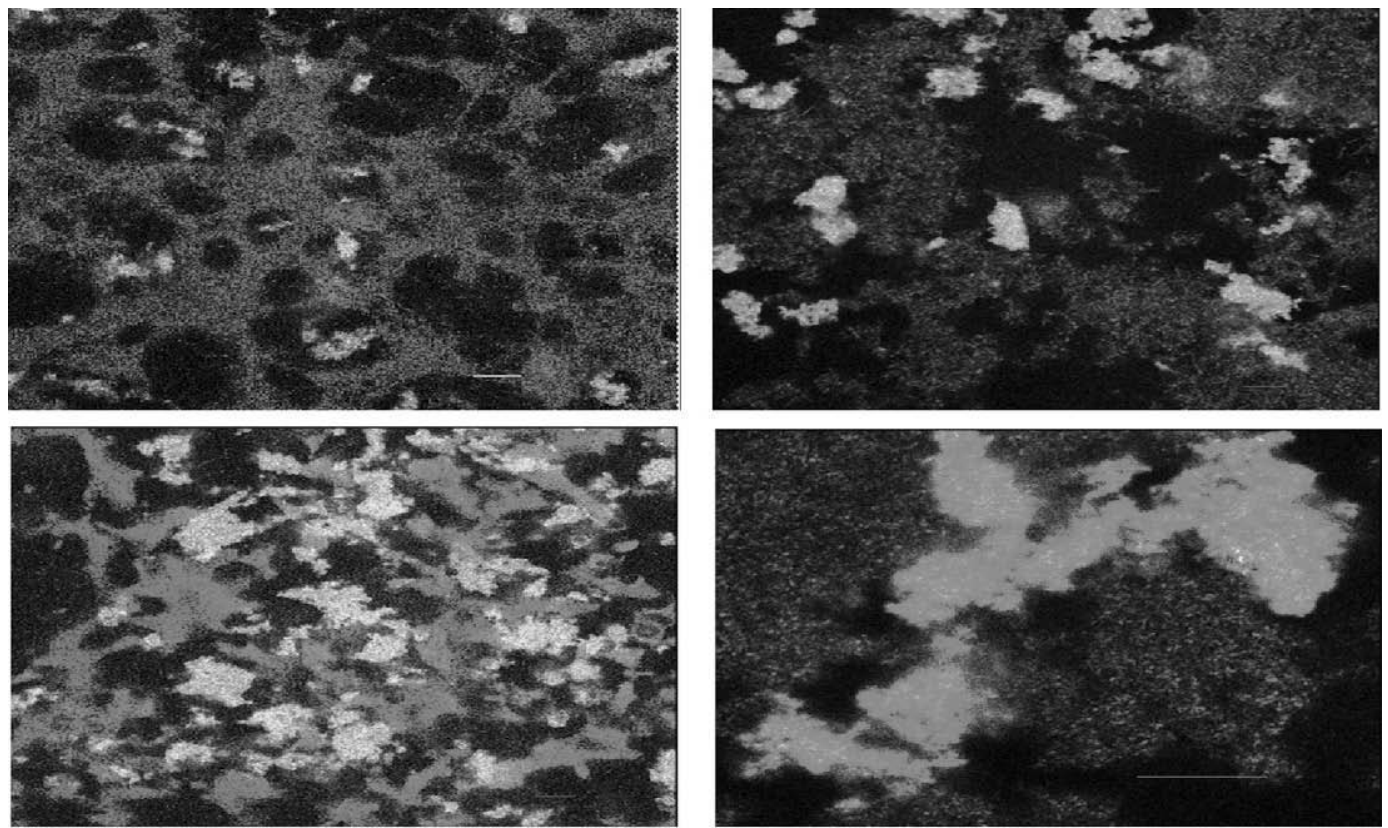

Figure 6. Distribution of exopolysaccharides (EPS) in set (left) and stirred (right) yogurts made with a moderately ropy strain (top) and highly ropy strain $($ bottom $)$. Light grey $($ green $)=$ EPS; dark grey $($ red-orange $)=$ protein network; bar $=10 \mu m$. Source: Hassan et al. $(2002 b)$. Color figure available at http://jds.fass.org/content/vol91/issue4/. 

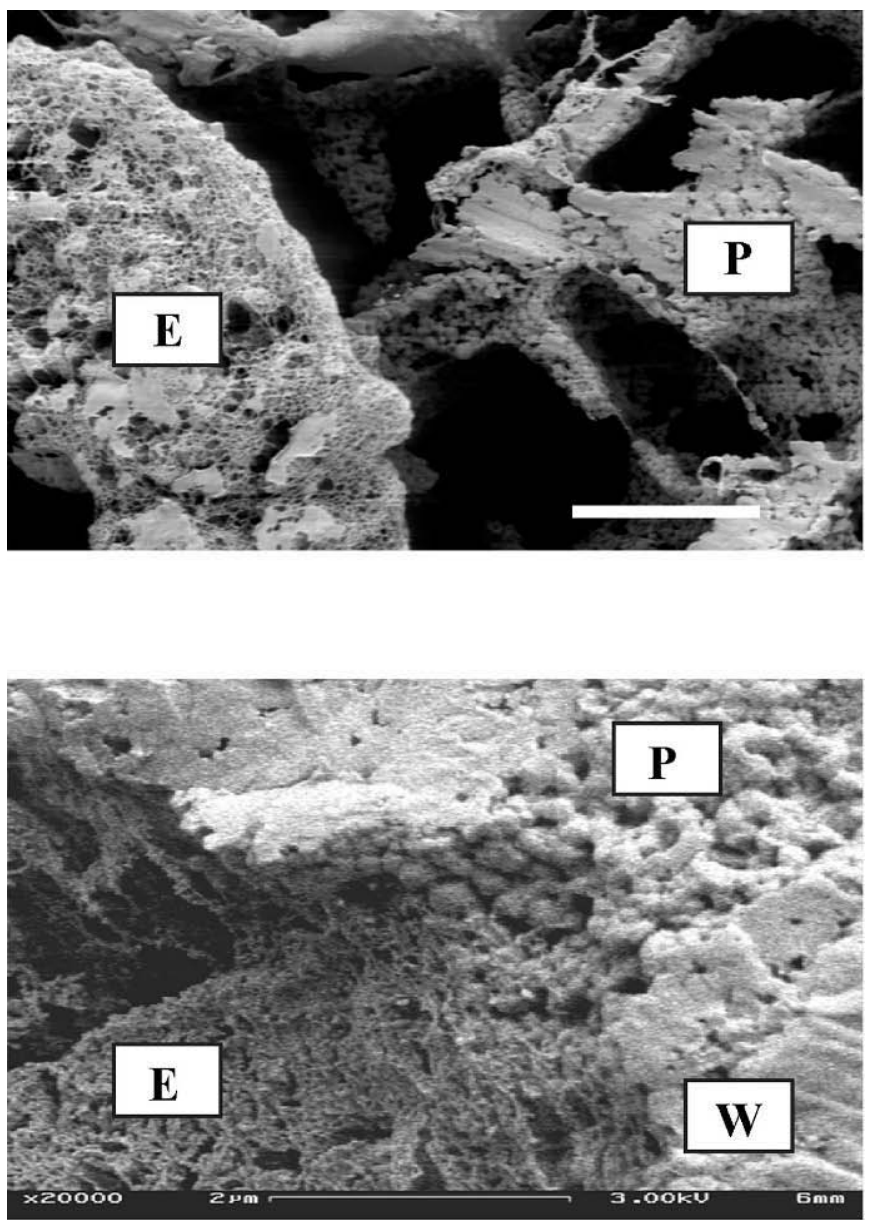

Figure 7. Cryo-scanning electron microscopy images of milk fermented with a moderately ropy strain (top) and a highly ropy strain (bottom). Specimens were etched for $10 \mathrm{~min} . \mathrm{P}=$ protein, $\mathrm{E}=$ exopolysaccharides, and $\mathrm{W}=$ casein aggregates covered with frozen water; bar (top image) $=5 \mu \mathrm{m}$. Source: Hassan et al. (2003a). Reprinted from Int. Dairy J. vol. 13, Observation of bacterial exopolysaccharide in dairy products using cryo-scanning electron microscopy, Hassan, AN, Frank, JF, and Elsoda, M. @ 2003, with permission from Elsevier.

forming cultures produced fermented milk with greater viscosity, hysteresis loop, water-holding capacity, and consistency coefficient and lower yield stress, flow behavior index, curd tension, and firmness than did nonencapsulated cultures.

\section{Ropy EPS}

The effect of ropy cultures on the physical characteristics of fermented milks has been extensively studied (Cerning, 1990; Marshall and Rawson, 1999; De Vuyst et al., 2001; Ruas-Madiedo et al., 2002; Hassan et al., $2003 \mathrm{~b})$. One of the major sources of confusion in the literature is that the terms "ropy" and "EPS-producing" are used interchangeably. As mentioned above, some nonropy strains produce significant amounts of EPS.

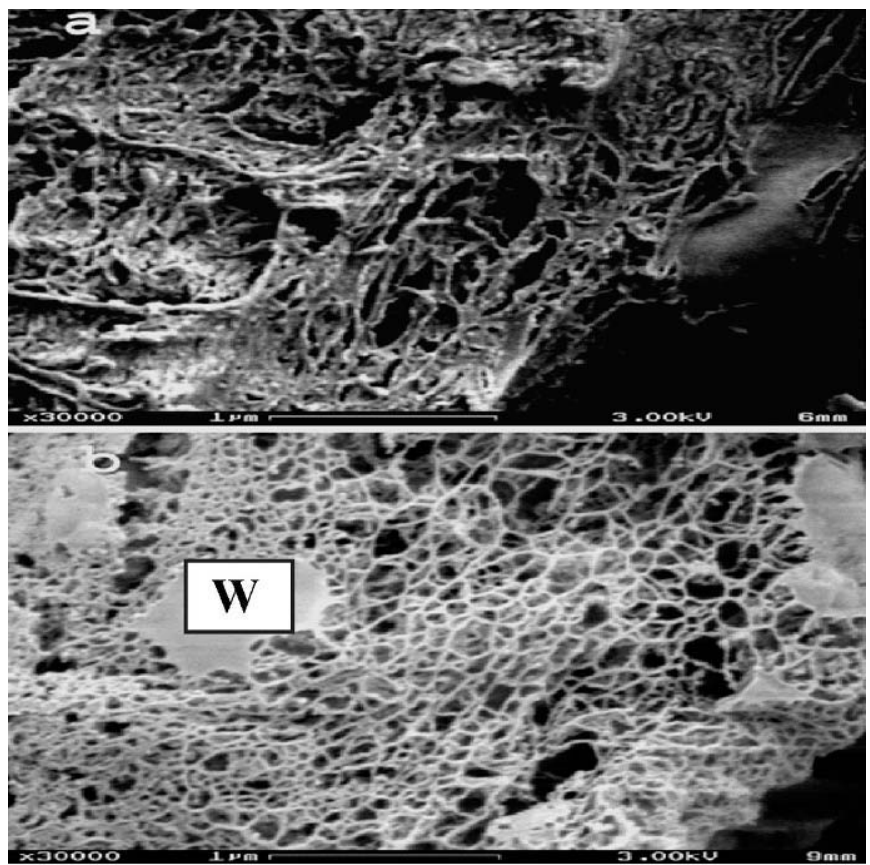

Figure 8. Cryo-scanning electron microscopy images of exopolysaccharides (EPS) produced by a highly ropy strain (top) and a moderately ropy strain (bottom). Specimens were etched for $10 \mathrm{~min}$. $\mathrm{W}=$ frozen water. Source: Hassan et al. (2003a). Reprinted from Int. Dairy J. vol. 13, Observation of bacterial exopolysaccharide in dairy products using cryo-scanning electron microscopy, Hassan, AN, Frank, JF, and Elsoda, M. (C) 2003, with permission from Elsevier.

Therefore, published work should be interpreted very cautiously. Ropiness is evaluated by stirring yogurt, pulling a small portion, and measuring the length of the thread formed. A higher hysteresis loop was observed in ropy yogurt than in nonropy yogurt (Folkenberg et al., 2006). The hysteresis loop indicates the level of structure breakdown during shearing. Hassan et al. (1996a) suggested that the larger hysteresis loop in the EPSpositive yogurt indicates more structure breakdown due to disturbance of EPS-EPS interactions or EPSprotein interactions. Such interactions are absent in the EPS-negative yogurt, which shows a smaller hysteresis area. Folkenberg et al. (2006) speculated that EPS physically interfered with reassociation of casein fragments resulting from shearing, leading to increased hysteresis area. Generally, ropy yogurt is creamier, smoother (less granular), thicker, and less firm (Folkenberg et al., 2006). However, major variations in such attributes, which could not be directly related to the level of ropiness, were seen among ropy yogurts (Folkenberg et al., 2006). Interestingly, an EPS-producing culture of Strep. thermophilus produced creamy yet firm yogurt (Folkenberg et al., 2006). Such cultures would be commercially attractive because creaminess is often associated with high ropiness, which is not desirable 
by consumers. Important factors influencing function of EPS in yogurt are their molecular characteristics (molecular weight, degree of branching, radius of gyration, charge, and so on) and their ability to interact with milk proteins (whey protein-casein complex in yogurt). Because ropiness decreases curd firmness, it is expected to increase syneresis. Although Folkenberg et al. (2006) confirmed this hypothesis, other researchers reported decreased syneresis in the ropy yogurt (Cerning, 1990; Marshall and Rawson, 1999; Amatayakul et al., 2006). The reason for the disagreement on the effect of EPSproducing cultures on syneresis is because of differences in the methods used for measuring syneresis (Amatayakul et al., 2006; Folkenberg et al., 2006).

\section{APPLICATIONS OF EPS-PRODUCING CULTURES IN CHEESE}

\section{Reduced-Fat Cheddar Cheese}

Cheddar cheese is made using a combination of carefully selected starter cultures. Such cultures should meet 4 main criteria: rapid acid production, bacteriophage resistance, salt sensitivity, and ripening activity (Hassan and Frank, 2001b). Fat reduction is associated with many textural and functional defects in cheese (Mistry, 2001). The high casein content in reduced-fat Cheddar cheese imparts a firm and rubbery body and texture (Emmons et al., 1980; Mistry and Anderson, 1993; Metzger and Mistry, 1995; Mistry, 2001).

Exopolysaccharide-producing cultures are good candidates for reduced-fat Cheddar cheese making for several reasons. They have the ability to bind water and increase the moisture in the nonfat substance (MNFS) with no need to modify the cheese-making protocol. This is an important function because fat reduction results in lower MNFS. The MNFS plays a major role in texture development in cheese and it would be very desirable to increase it to levels similar to those in the full-fat counterpart (Lawrence and Gilles, 1980; Fenelon et al., 1999). To increase the moisture in reduced-fat Cheddar cheese, manufacturers lower cooking temperature and drain the whey at a higher $\mathrm{pH}$ value. Such modifications might have a negative effect on cheese flavor development (Mistry, 2001). In addition, increasing moisture might result in increased levels of free moisture in cheese. During the first few weeks of ripening, redistribution of free water would produce pasty, difficult to shred reduced-fat cheeses. Exopolysaccharides increase moisture retention by water binding or entrapment within their 3-dimensional network. In addition, EPS seem to act as nuclei for the formation of large pores in cheese (Figure 10). Moisture bound or entrapped in the EPS might not be available for protein hydration and would not produce pasty cheese. Exopolysacchar-
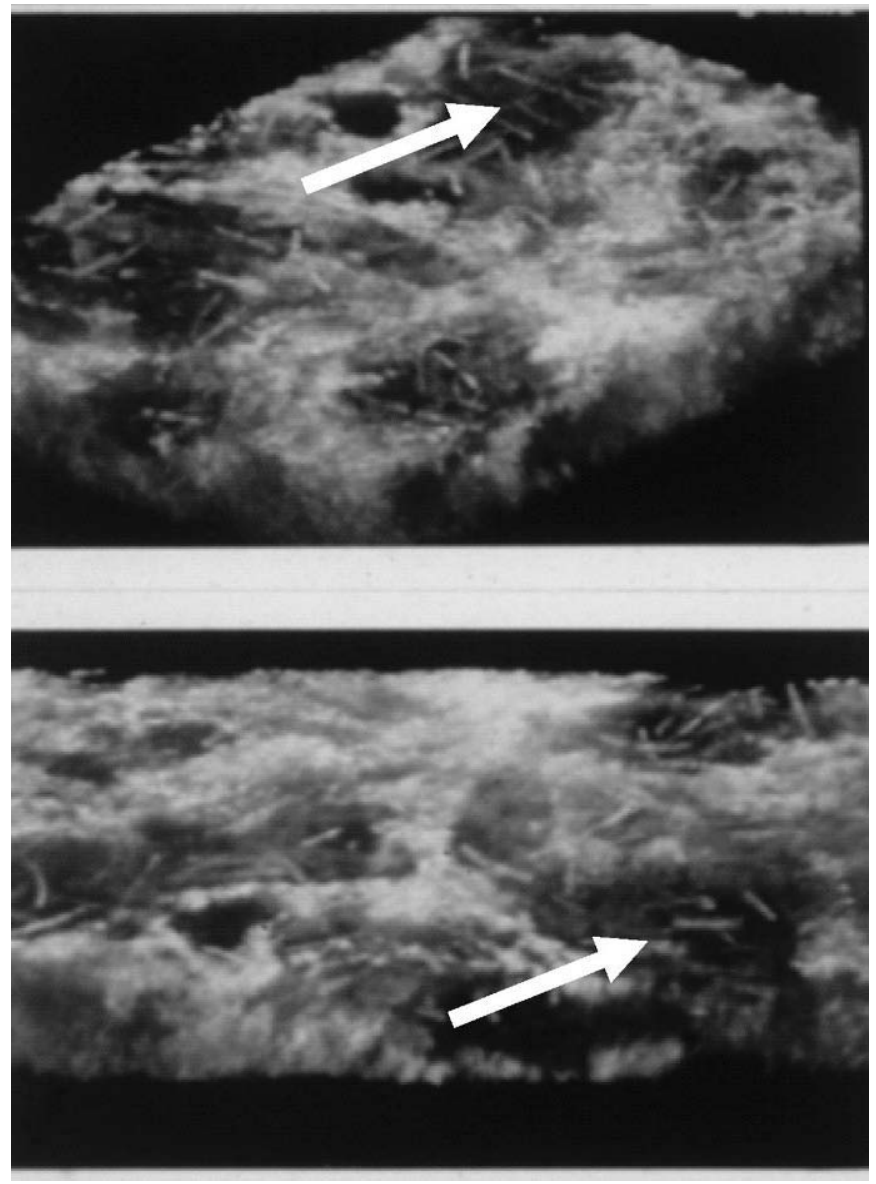

Figure 9. Volume rendering of yogurt made using capsule-forming nonropy cultures to give different views compiled from 60 optical sections obtained by using confocal scanning laser microscopy in reflectance mode. The rendered image is approximately $36 \mu \mathrm{m}$ thick. Arrows indicate pores occupied by capsule-forming bacterial cells. Source: Hassan et al. (1995b).

ides also increase the viscosity of the aqueous phase in cheese and modify its flow characteristics. In addition, EPS interfere with protein-protein interactions physically or through their interaction with proteins.

Several studies highlighted the positive effect of EPSproducing cultures on the physical and functional properties of reduced-fat Cheddar cheese (Awad et al., 2005a,b; Dabour et al., 2005, 2006; Hassan and Awad, 2005; Hassan et al., 2005). A 33\% reduced-fat Cheddar cheese had similar textural characteristics as a fullfat cheese if made with a ropy strain of Lactococcus lactis ssp. cremoris (JFR1). Furthermore, the changes in the texture of full-fat cheese and reduced-fat cheese made with the EPS-positive strain JFR1 followed the same pattern. Unlike reduced-fat cheese made with no EPS, hardness of both full-fat cheese and reduced-fat cheese made with the JFR1 culture increased during the first month of ripening. This is a significant im- 


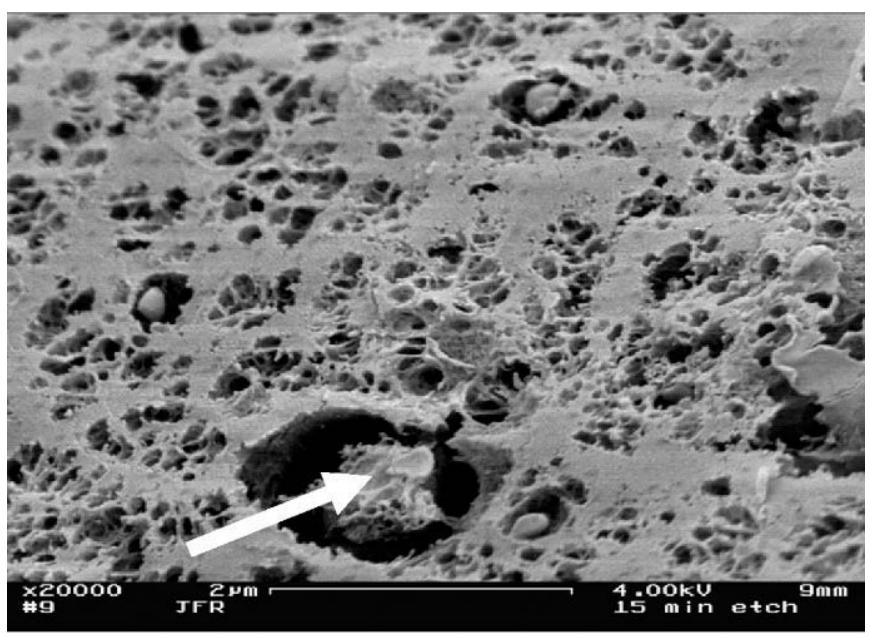

Figure 10. Microstructure of reduced-fat Cheddar cheese made with a highly ropy culture of Lactococcus lactis ssp. cremoris (JFR1). Arrow indicates exopolysaccharides in a large pore. Source: Hassan and Awad (2005).

provement in reduced-fat cheese containing high moisture levels, and would have a direct impact on reducedfat cheese used as an ingredient. Interestingly, both full-fat cheese and the EPS-positive cheese had a similar melting pattern (Awad et al., 2005b). They both became creamy and retained their shape for a longer period compared with the EPS-negative cheese, which spread quickly and separated into solids and liquid when heated. Due to the improvement in texture of EPS-containing reduced-fat Cheddar cheese, panelists did not detect any differences in texture between fullfat and reduced-fat cheeses (Awad et al., 2005b). Furthermore, the EPS-positive reduced-fat cheese developed the texture of aged cheese much earlier in the aging process. The EPS-producing cultures reduced the viscoelastic moduli of reduced-fat Cheddar cheese (Hassan et al., 2005). Whereas the moduli increased during the first month of ripening of full-fat cheese and EPSpositive reduced-fat cheeses, it decreased in the control cheese. This avoided too much softening in the former cheeses. In addition, the 6-mo-old reduced-fat cheese maintained lower viscoelastic moduli than did the EPSnegative cheeses (Hassan et al., 2005). Scanning electron microscopy micrographs showed that fresh, EPSnegative, reduced-fat cheese contained fewer and larger pores than did the EPS-positive cheese (Figure 11). During ripening, minimal changes in the porosity of the EPS-positive and full-fat cheeses were seen (Hassan and Awad, 2005). However, major changes in the size and distribution of pores were observed during ripening of reduced-fat cheese containing no EPS (Hassan and Awad, 2005). Major changes in the size and distribution of pores in reduced-fat cheese made with no EPS com-
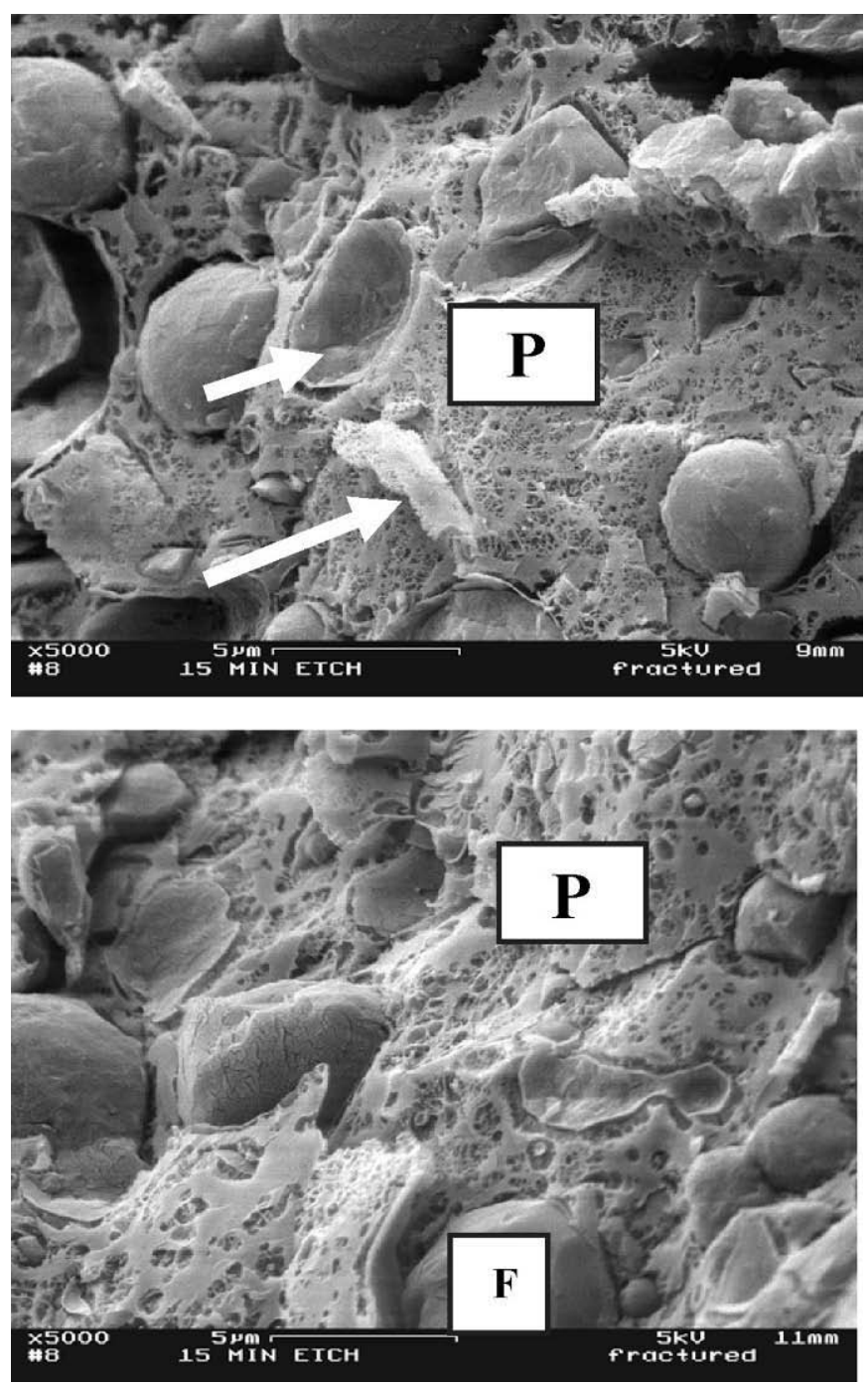

Figure 11. Microstructure of reduced-fat cheeses made with a highly ropy culture of Lactococcus lactis ssp. cremoris (JFR1) (top) and an exopolysaccharide-nonproducing culture (bottom). Long arrow indicates exopolysaccharide; short arrow indicates depression originally occupied by a fat globule and formed as a result of surface fracture; $\mathrm{P}=$ background protein network; $\mathrm{F}$ = fat. Source: Hassan and Awad (2005).

pared with the EPS-containing cheese indicated more extensive water redistribution in the former cheese (Hassan and Awad, 2005). The presence of EPS prevented extensive water redistribution in reduced-fat cheese during the first month of ripening. Figure 12 shows that the 6-mo-old EPS-negative cheese contained fewer protein strands than did both full-fat cheese and the EPS-positive cheese. This might explain the major differences in the melting pattern between the 2 groups of cheeses. Protein strands provide resistance during heating, leading to the more uniform melting and more gradual loss of cheese shape in the full-fat cheese and 

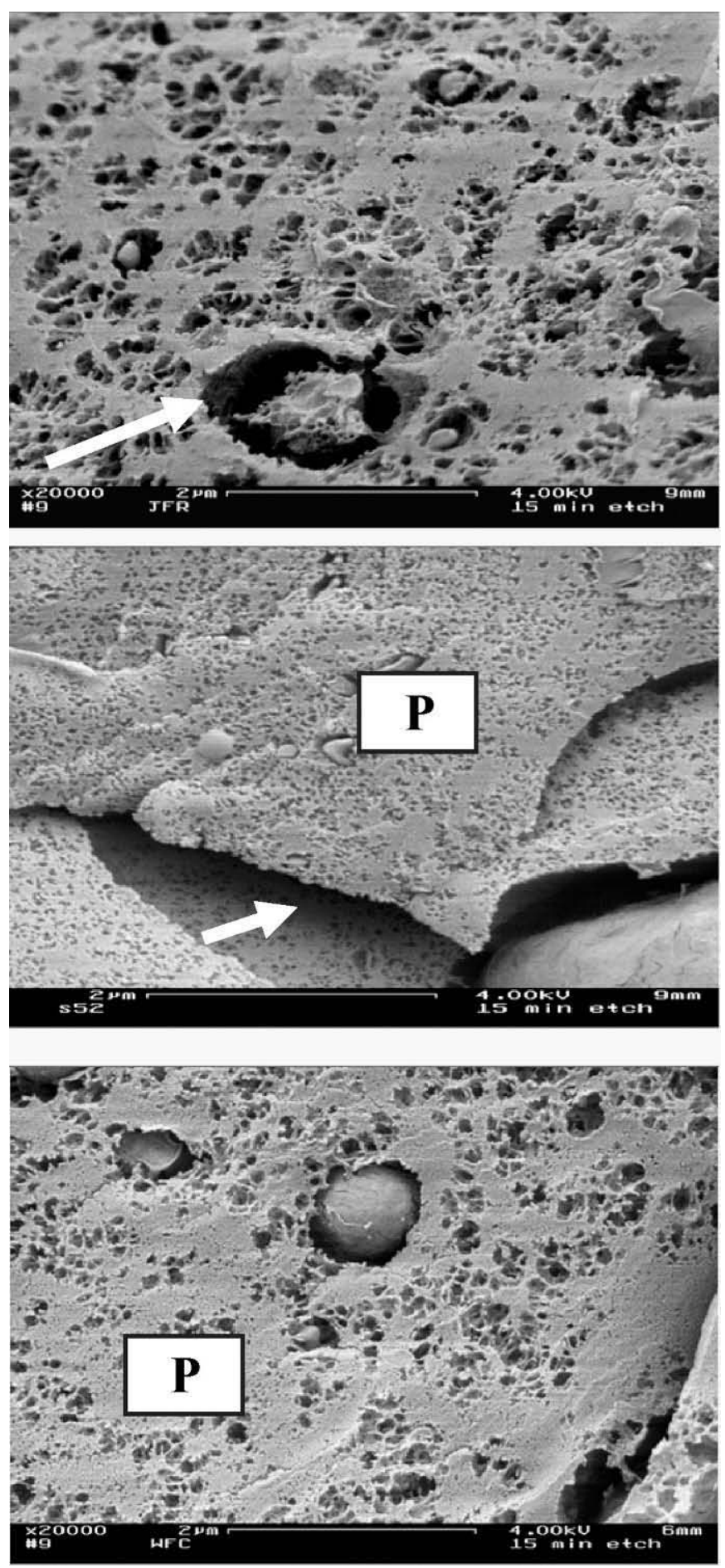

Figure 12. Microstructure of 6-mo-old reduced-fat Cheddar cheese made with a highly ropy strain of Lactococcus lactis ssp. cremoris (JFR1) (top) and an exopolysaccharide (EPS)-nonproducing culture (middle) and full-fat cheese (bottom). Long arrow indicates a large pore occupied by EPS; short arrow indicates a fracture in the protein network; $\mathrm{P}=$ background protein network. Source: Hassan and Awad (2005).
EPS-positive reduced-fat cheese. The protein network in the full-fat cheese and EPS-positive reduced-fat cheese was continuous, whereas the layered structure responsible for the rubbery texture was observed in the EPS-negative cheese (Figure 12).

Bitterness is a common defect in reduced-fat Cheddar cheeses. This is due to increased moisture levels and reduced fat. Because of the increased residual chymosin activity (RCA) associated with the high moisture in the reduced-fat cheese and lack of a good peptidolytic system in the starter culture, bitterness developed after 2 to 3 mo of ripening of reduced-fat Cheddar cheese made with an EPS-producing culture (Awad et al., 2005a,b; Agrawal and Hassan, 2007). The HPLC analysis showed a significant increase in the level of hydrophobic peptides causing bitterness in the aged EPSpositive cheese (Table 3). Because the EPS-positive strain was not a typical Cheddar cheese starter culture, it did not have an adequate peptidolytic system to further hydrolyze the bitter peptides to amino acids (Awad et al., 2005a). Ultrafiltration of cheese milk at a low rate $(1.2 \times)$ produced RCA in EPS-positive reduced-fat cheese similar to that in the EPS-negative cheese (Agrawal and Hassan, 2007). This reduction in RCA resulted in lower bitterness. Because UF reduced the RCA per gram of protein to a level similar to that in the EPSnegative cheese, containing much less moisture, the contribution of chymosin to cheese proteolysis would be the same in both cheeses. Because of the high ability of EPS to bind water, the combination of EPS-producing cultures and increasing moisture retention by modifying the standard cheese-making protocol such as lowering the cooking temperature might produce cheese with too-high moisture levels and associated problems such as open structure, weak texture, and syneresis during aging (Dabour et al., 2006). Syneresis was not observed in reduced-fat Cheddar cheese containing only 47 to $48 \%$ moisture (Awad et al., 2005a) and made with the same culture used by Dabour et al. (2006).

Capsule-forming Strep. thermophilus used as an adjunct in making reduced-fat Cheddar cheese also improved the texture of reduced-fat Cheddar cheese (Awad et al., 2005b; Rynne et al., 2007). However, the effect of such a culture was less pronounced than that produced by highly ropy strains of $L$. lactis ssp. cremoris. Although Dabour et al. (2005) found that EPSproducing cultures had no effect on fat recovery in cheese, Rynne et al. (2007) reported improved milk fat recovery when such cultures were used. Rynne et al. (2007) found also that the ropy EPS increased the efficiency of half-fat Cheddar cheese-making by improving the rennet coagulation properties, reducing cheesemaking time, and increasing moisture. 
Table 3. Ratio of hydrophilic to hydrophobic peptides separated by reverse phase-HPLC and percentage of hydrophobic peptides of total peptides in full-fat and reduced-fat Cheddar cheeses during ripening (from Awad et al., 2005a)

\begin{tabular}{lccccc}
\hline & \multicolumn{5}{c}{ Ripening time $(\mathrm{d})$} \\
\cline { 2 - 5 } Treatment $^{1}$ & 1 & 30 & 60 & 120 & 180 \\
\hline Ratio of hydrophilic to hydrophobic peptides & & & & \\
FFC & $1.9^{\mathrm{a}, \mathrm{A}}$ & $0.8^{\mathrm{a}, \mathrm{D}}$ & $1.2^{\mathrm{a}, \mathrm{C}}$ & $1.5^{\mathrm{a}, \mathrm{B}}$ & $1.9^{\mathrm{a}, \mathrm{A}}$ \\
RFC & $1.4^{\mathrm{b}, \mathrm{B}}$ & $1.0^{\mathrm{a}, \mathrm{C}}$ & $1.1^{\mathrm{b}, \mathrm{C}}$ & $1.3^{\mathrm{b}, \mathrm{B}}$ & $1.8^{\mathrm{a}, \mathrm{A}}$ \\
RF-JFR1 & $1.2^{\mathrm{c}, \mathrm{A}}$ & $0.5^{\mathrm{b}, \mathrm{B}}$ & $0.5^{\mathrm{c}, \mathrm{B}}$ & $0.4^{\mathrm{c}, \mathrm{C}}$ & $0.5^{\mathrm{b}, \mathrm{B}}$ \\
Hydrophobic peptides, \% of total peptides & & & & & \\
FFC & $34.3^{\mathrm{c}, \mathrm{D}}$ & $55.6^{\mathrm{b}, \mathrm{A}}$ & $44.5^{\mathrm{b}, \mathrm{B}}$ & $40.7^{\mathrm{b}, \mathrm{C}}$ & $34.4^{\mathrm{b}, \mathrm{D}}$ \\
RFC & $41.8^{\mathrm{b}, \mathrm{B}}$ & $50.8^{\mathrm{b}, \mathrm{A}}$ & $47.9^{\mathrm{b}, \mathrm{A}}$ & $44.3^{\mathrm{b}, \mathrm{B}}$ & $36.0^{\mathrm{b}, \mathrm{C}}$ \\
RF-JFR1 & $45.8^{\mathrm{a}, \mathrm{C}}$ & $65.7^{\mathrm{a}, \mathrm{B}}$ & $68.5^{\mathrm{a}, \mathrm{B}}$ & $72.7^{\mathrm{a}, \mathrm{A}}$ & $67.3^{\mathrm{a}, \mathrm{B}}$ \\
\hline a-c Means within the same column with different superscript letters are significantly different $(P<0.05)$. \\
A-DMeans within the same row with different superscript letters are significantly different $(P<0.05)$. \\
${ }^{1}$ FFC = full-fat Cheddar cheese; RFC = exopolyaccharide (EPS)-negative reduced-fat Cheddar cheese; RF- \\
JFR1 = EPS-positive reduced-fat Cheddar cheese.
\end{tabular}

Whey viscosity is a major concern for the whey processing industry. Some of the EPS produced during Cheddar cheese making is released in the whey. The amount of EPS in the whey depends on the time between culture addition and whey drainage, amount of EPS produced, and ability of EPS to interact with the protein matrix. The ability of EPS to interact with milk proteins depends on the type of EPS, the level of whey protein denaturation in cheese milk, and $\mathrm{pH}$. Temperature and $\mathrm{pH}$ are among the important factors affecting EPS production by a given strain. Awad et al. (2005a,b) used a L. lactis ssp. cremoris strain that produces less ropiness as the temperature of the medium increases with optimum production at $25^{\circ} \mathrm{C}$. Therefore, conditions used in making Cheddar were not optimum for ropiness production by this strain and whey viscosity was not affected. However, when the temperature of cooking was lowered from 39 to $35^{\circ} \mathrm{C}$, the viscosity of whey increased slightly (Dabour et al., 2005). Studying the structure of EPS, factors affecting their production, and their interaction with milk proteins would be essential for successful application of EPS-producing cultures in making reduced-fat Cheddar cheese.

Most, if not all, typical Cheddar cheese starters do not produce EPS. Special cultures are used in making reduced-fat Cheddar cheese. Such cultures are used to overcome the flavor defects associated with reducedfat cheese such as low flavor and aroma intensities, bitterness, and unclean flavors (Fenelon et al., 1999). It is unlikely that EPS-producing cultures can be found that also meet such specific requirements in reducedfat Cheddar cheese. In addition, the desirable texture in reduced-fat cheese would depend on the molecular characteristics of EPS, which differ considerably among strains. Therefore, production of EPS-positive strains with limited acid production through genetic modifica- tions or other means would be the best way for incorporation of such cultures in reduced-fat Cheddar cheese.

\section{Process Cheese}

Exopolysaccharide-producing cultures modify natural cheese characteristics directly by increasing water retention and interfering with protein-protein interactions or indirectly through their influence on proteolysis, $\mathrm{pH}$, and water redistribution, which affect the physicochemical changes during ripening. Exopolysaccharide-containing base cheese has an impact on process cheese characteristics (Hassan et al., 2007). However, it is difficult to directly relate modifications in process cheese characteristics to the presence of EPS. For example, the increase in moisture in reduced-fat Cheddar cheese by EPS-producing cultures results in an increase in RCA and proteolysis and lower $\mathrm{pH}$. Proteolysis and $\mathrm{pH}$ of the base cheese are the main factors influencing process cheese characteristics (Hassan et al., 2007).

Modifications in base cheese do not necessarily affect the process cheese. This is because different factors influence the characteristics of base and process cheeses. There are many differences between the base and process cheese systems. It is easier to control moisture in process cheese than in base cheese. Moisture affects base cheese characteristics directly or indirectly through its influence on proteolysis, RCA, protein hydration, and $\mathrm{pH}$. However, the role of moisture is relatively more direct and less complex in process cheese. Because of the addition of emulsifying salts, the protein is more hydrated in the process cheese than in the base cheese. Differences in protein hydration between the base and process cheeses might affect EPS-protein interactions and cheese characteristics. A more severe heat treatment is used in making process cheese than in treating base cheese curd (around $39^{\circ} \mathrm{C}$ in Cheddar). 
Table 4. Characteristics of process cheese and base Cheddar cheese made with exopolysaccharide-producing and nonproducing cultures ${ }^{1,2}$ (adapted from Hassan et al., 2005, 2007; Awad et al., 2005a,b)

\begin{tabular}{|c|c|c|c|c|}
\hline \multirow[b]{2}{*}{ Parameter $^{1}$} & \multicolumn{4}{|c|}{ Treatment $^{2}$} \\
\hline & $A-2 d$ & B-2 d & $\mathrm{A}-1 \mathrm{mo}$ & B-1 mo \\
\hline $\begin{array}{l}\text { Hardness, N } \\
\text { Adhesiveness, J } \\
\text { Gumminess, N } \\
\text { Chewiness, J } \\
\mathrm{G}^{\prime}, \mathrm{kPa} \\
\mathrm{G}^{\prime \prime}, \mathrm{kPa} \\
\mathrm{G}^{*}, \mathrm{kPa} \\
\mathrm{J}_{\max }, 1 / \mathrm{Pa} \times 10^{-5} \\
\mathrm{WSN}^{-\mathrm{TN}}{ }^{3} \% \\
\mathrm{pH}^{3} \\
\text { Flow, } \%\end{array}$ & $\begin{array}{l}22^{\mathrm{a}}\left(23^{\mathrm{A}}\right) \\
0.13^{\mathrm{a}}\left(0.18^{\mathrm{A}}\right) \\
19^{\mathrm{a}}\left(20^{\mathrm{A}}\right) \\
84^{\mathrm{a}}\left(97^{\mathrm{A}}\right) \\
59^{\mathrm{a}}\left(143^{\mathrm{A}}\right) \\
18^{\mathrm{a}}\left(39^{\mathrm{A}}\right) \\
62^{\mathrm{a}}\left(149^{\mathrm{A}}\right) \\
13^{\mathrm{c}}\left(5.19^{\mathrm{C}}\right) \\
\left(4.0^{\mathrm{D}}\right) \\
\left(5.26^{\mathrm{A}}\right) \\
68^{\mathrm{b}}\left(57^{\mathrm{C}}\right)\end{array}$ & $\begin{array}{l}16^{\mathrm{b}}\left(15^{\mathrm{C}}\right) \\
0.13^{\mathrm{a}}\left(0.21^{\mathrm{A}}\right) \\
14^{\mathrm{b}}\left(13^{\mathrm{C}}\right) \\
60^{\mathrm{b}}\left(57^{\mathrm{C}}\right) \\
46^{\mathrm{b}}\left(86^{\mathrm{C}}\right) \\
15^{\mathrm{b}}\left(29^{\mathrm{C}}\right) \\
49^{\mathrm{b}}\left(91^{\mathrm{C}}\right) \\
17^{\mathrm{c}}\left(9.06^{\mathrm{A}}\right) \\
\left(4.7^{\mathrm{C}}\right) \\
\left(5.22^{\mathrm{A}}\right) \\
72^{\mathrm{a}}\left(70^{\mathrm{B}}\right)\end{array}$ & $\begin{array}{l}7.5^{\mathrm{c}}\left(19^{\mathrm{B}}\right) \\
0.07^{\mathrm{b}}\left(0.14^{\mathrm{A}}\right) \\
6.0^{\mathrm{c}}\left(16^{\mathrm{B}}\right) \\
26^{\mathrm{c}}\left(76^{\mathrm{B}}\right) \\
35^{\mathrm{c}}\left(104^{\mathrm{B}}\right) \\
12^{\mathrm{c}}\left(34^{\mathrm{B}}\right) \\
37^{\mathrm{c}}\left(109^{\mathrm{B}}\right) \\
22^{\mathrm{b}}\left(6.63^{\mathrm{B}}\right) \\
\left(8.3^{\mathrm{B}}\right) \\
\left(5.12^{\mathrm{A}}\right) \\
70^{\mathrm{ab}}\left(81^{\mathrm{A}}\right)\end{array}$ & $\begin{array}{l}4.2^{\mathrm{d}}\left(15^{\mathrm{C}}\right) \\
0.07^{\mathrm{b}}\left(0.17^{\mathrm{A}}\right) \\
3.2^{\mathrm{d}}\left(12^{\mathrm{D}}\right) \\
14^{\mathrm{d}}\left(52^{\mathrm{C}}\right) \\
26^{\mathrm{d}}\left(100^{\mathrm{B}}\right) \\
9.0^{\mathrm{d}}\left(33^{\mathrm{B}}\right) \\
27^{\mathrm{d}}\left(106^{\mathrm{B}}\right) \\
47^{\mathrm{a}}\left(6.71^{\mathrm{B}}\right) \\
\left(11.0^{\mathrm{A}}\right) \\
\left(5.05^{\mathrm{B}}\right) \\
71^{\mathrm{ab}}\left(71^{\mathrm{B}}\right)\end{array}$ \\
\hline \multicolumn{5}{|c|}{$\begin{array}{l}\text { Lowercase letters indicate differences among process cheeses and uppercase letters indicate differences } \\
\text { among base cheeses (base cheese values are in parentheses). }\end{array}$} \\
\hline \multicolumn{5}{|c|}{$\begin{array}{l}{ }^{2} \mathrm{~A}-2 \mathrm{~d}=\text { process cheese made from } 2 \text {-d-old EPS-negative Cheddar cheese base (in parentheses); } \mathrm{B}-2 \mathrm{~d}= \\
\text { process cheese made from 2-d-old EPS-positive Cheddar cheese base (in parentheses); A-1 mo = process } \\
\text { cheese made from 1-mo-old EPS-negative Cheddar cheese base (in parentheses); } \mathrm{B}-1 \text { mo = process cheese } \\
\text { made from 1-mo-old EPS-positive Cheddar cheese base (in parentheses). }\end{array}$} \\
\hline
\end{tabular}

The severe heat treatment in process cheese making could negatively affect the functionality of EPS. Therefore, the function of EPS in process cheese and base cheese is expected to be different. Ability of EPS to entrap water is not an important factor in process cheese because the moisture level can be easily controlled. Awad et al. (2005a) found that even after 2 $\mathrm{d}$ of manufacture, EPS-positive base cheese contained greater levels of proteolysis products due to increased residual chymosin activity and moisture. Table 4 shows characteristics of process cheese made from EPS-positive and EPS-negative base cheeses. The EPS-positive process cheese was less rigid, gummy, and chewy, and more deformable than the EPS-negative one. No differences were found in $\mathrm{pH}$ of base cheeses, but the level of water-soluble nitrogen was greater in the 2-d-old EPS-positive base cheese than in the EPS-negative one, likely because of increased moisture and RCA in the former cheese (Awad et al., 2005a). Greater differences were seen between process cheeses made from 1-moold EPS-positive and EPS-negative base cheeses than those between the corresponding cheeses made from 2d-old base cheeses (Hassan et al., 2007). This was due to greater differences in $\mathrm{pH}$ and proteolysis between the 1-mo-old base cheeses compared with those between the 2-d-old cheeses.

No relationship was found between the textural characteristics of the base and process cheeses (Table 4). For example, although the rigidity (complex modulus) increased during the first month of ripening of the EPS- positive base cheese, process cheese made from 1-moold base cheese was less rigid than that made from the 2-d-old cheese. This was because of more extensive proteolysis and lower $\mathrm{pH}$ in the 1-mo-old base cheese compared with 2-d-old cheeses (Table 4). Also, although large differences were found in percentage flow between the 1-mo-old EPS-positive and EPS-negative base cheeses, the flow of the resulting process cheeses was similar (Table 4). Hassan et al. (2007) concluded that proteolysis and $\mathrm{pH}$ of base cheese are the most important factors influencing process cheese characteristics. Exopolysaccharides act as nuclei for the formation of large pores in base cheese (Figure 10). Such pores reduce the rigidity of cheese. However, when cheese is melted during process cheese making, the importance of such pores is minimized and changes in base cheese at the molecular level such as proteolysis and calcium removal due to reduction in $\mathrm{pH}$ seem to be more important (Hassan et al., 2007). The effect of EPS on reduced-fat process cheese characteristics is limited compared with changes that take place during the first month of the base cheese ripening (Hassan et al., 2007).

\section{Soft Cheese}

Very limited information is available on the application of EPS-producing cultures in soft cheeses. Because the characteristics of the final cheese are governed by structural characteristics of the coagulum, the type and amount of EPS in cheese milk before coagulation are 


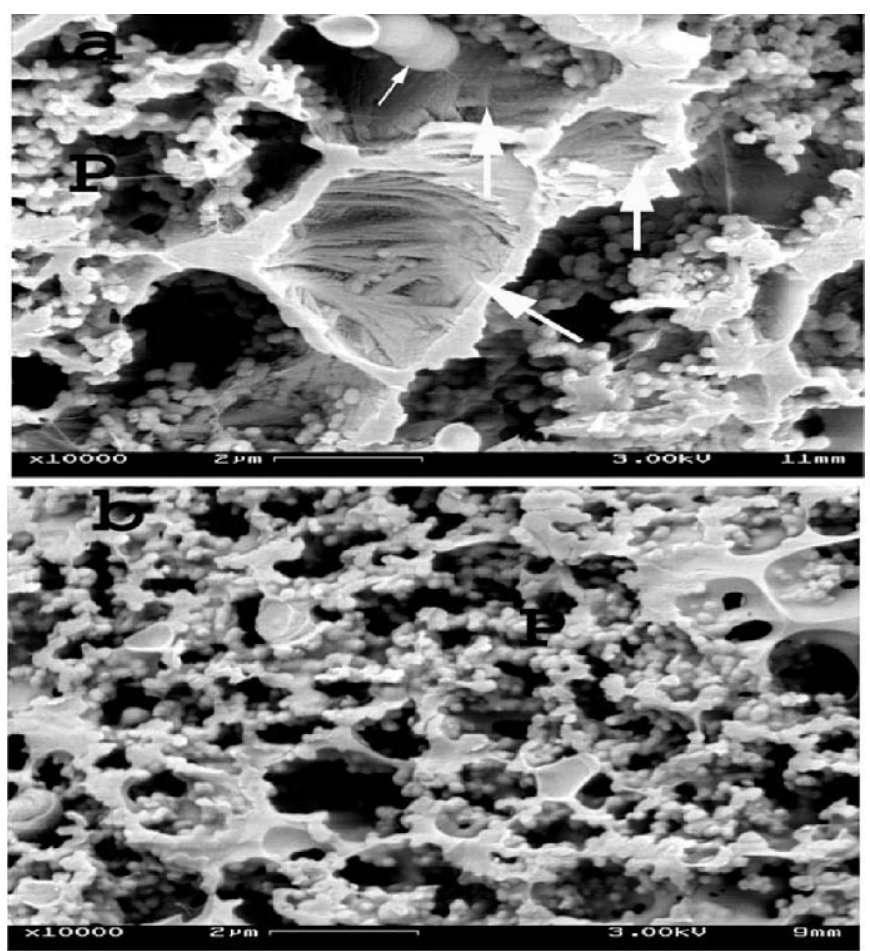

Figure 13. Photomicrographs of acid-coagulated cheese (Karish) made with an exopolysaccharide (EPS)-producing culture (top) and a nonproducing culture (bottom). Large arrows indicate masses of EPS; small arrows indicate bacterial cells. Note the dense protein network in cheese made with the nonproducing culture (bottom). Source: Hassan et al. (2003a). Reprinted from Int. Dairy J. vol. 13, Observation of bacterial exopolysaccharide in dairy products using cryo-scanning electron microscopy, Hassan, AN, Frank, JF, and Elsoda, M. (C) 2003, with permission from Elsevier.

important factors influencing the characteristics of the final cheese. Soft cheeses are made using either acid or rennet coagulation. Manufacture of some acid-coagulated soft cheeses (e.g., cottage and Karish) allows significant growth and acidification by starter cultures before coagulation. In such cheeses, the effect of EPS is pronounced (Hassan et al., 2004). In some rennetcoagulated soft cheeses such as Mozzarella, a significant growth of starter culture takes place during cheese making, whereas in other varieties such as Feta the growth of starter during cheese making is minimal.

Mozzarella Cheese. Ropy and capsular EPS increased moisture retention and improved meltability in Mozzarella cheese (Low et al., 1998; Perry et al., 1998; Petersen et al., 2000; Broadbent et al., 2003). Cheese made with a ropy strain contained greater moisture levels and had better melting characteristics than did that made with a capsule-forming culture. However, due to a high moisture level (7\% greater than in control cheese), cheese made with the ropy culture was sticky, soft, difficult to shred, and expelled whey during heat- ing (Petersen et al., 2000). Another problem associated with using the ropy culture in making Mozzarella cheese is the significant increase in whey viscosity and the greater time required to ultrafilter it. A nonropy strain of Strep. thermophilus that produces a large capsule $(5 \mu \mathrm{m})$ increased moisture retention by a moderate level (3\%) and did not affect whey viscosity (Low et al., 1998; Petersen et al., 2000). This strain was recommended for making Mozzarella cheese. However, it would be difficult to draw a general conclusion on the advantage of the capsule-forming strains over the ropy strains in making Mozzarella cheese because there might be a ropy strain that would increase the moisture to levels similar to those produced by the capsule-forming nonropy strain. In addition, if the ropy EPS interact with proteins, most of them will be retained in the curd without noticeable increase in whey viscosity. Awad et al. (2005a) used a ropy strain of Strep. thermophilus that produced a percentage increase in moisture of reduced-fat Cheddar cheese similar to that produced by the capsule-forming nonropy strains used in making Mozzarella cheese by Petersen et al. (2000). A capsuleforming strain of Strep. thermophilus increased moisture of Mozzarella by only 1.25\% (Zisu and Shah, 2004). This increase in moisture was sufficient to reduce hardness, chewiness, and springiness and improve meltability of the low-fat cheese (Zisu and Shah, 2004). Because EPS was not detected in the cheese milk, Zisu and Shah (2004) suggested that most of the EPS was produced after coagulation and during cheese making. The EPSpositive Mozzarella cheese contained up to $41 \mathrm{mg}$ of EPS/g of cheese (Zisu and Shah, 2004). However, it is expected that the cheese contained greater levels of EPS that could not be recovered from the cheese matrix. Perry et al. (1998) found that whereas the increase in moisture in cheese made with EPS-producing culture in small manually stirred vats was $3 \%$, it was only $2 \%$ in cheese made in double-O vats. The difference in moisture retention was due to the agitation and cheese making time, which was longer in the double-O vats.

Acid-Coagulated Cheese (Karish). Karish is an Egyptian soft acid-coagulated cheese made from skim milk. This cheese is one of the cheeses that would greatly benefit from EPS-producing strains because of its very low fat content and inferior structure, the acidification method used in its manufacture that allows sufficient time for the culture to grow and produce EPS, and its high moisture content. Figure 13 shows that EPS formed large masses of a dense filamentous structure in Karish cheese. Such masses, although forming separate entities, seem to be interacting with the protein network. The presence of the EPS within the structure reduced protein-protein interactions and cheese 
Table 5. Viscoelastic properties of Karish cheese made with exopolysaccharide-producing $\left(\mathrm{EPS}^{+}\right)$and nonproducing $\left(\mathrm{EPS}^{-}\right)$cultures (from Hassan et al., 2004)

\begin{tabular}{lcc}
\hline Parameter $^{1}$ & EPS $^{+}$ & EPS $^{-}$ \\
\hline $\mathrm{G}^{\prime}, \mathrm{kPa}$ & $40.5^{\mathrm{a}}$ & $147.6^{\mathrm{b}}$ \\
$\mathrm{G}^{\prime \prime}$ at $1 \mathrm{~Hz}, \mathrm{kPa}$ & $13.1^{\mathrm{a}}$ & $46.9^{\mathrm{b}}$ \\
Strain at $30 \mathrm{~s}, \%$ & $1.96^{\mathrm{a}}$ & $0.40^{\mathrm{b}}$ \\
Strain at $500 \mathrm{~s}, \%$ & $0.12^{\mathrm{a}}$ & $0.025^{\mathrm{b}}$ \\
\hline
\end{tabular}

${ }^{\mathrm{a}, \mathrm{b}}$ Values within the same row with different superscript letters are significantly different $(P<0.05)$.

${ }^{1} \mathrm{G}^{\prime}=$ elastic modulus; $\mathrm{G}^{\prime \prime}=$ viscous modulus.

rigidity. Table 5 shows that the viscoelastic moduli were reduced by at least two-thirds when the EPS-producing culture was used. Cheese prepared with the EPS-positive culture was more deformable and did not recover its original structure as much as the control cheese (Table 5). Karish cheese made with the EPS-positive culture was softer, less adhesive and chewy, and more cohesive than the control cheese (Ahmed et al., 2004; François et al., 2004). The moisture level in the EPSpositive cheese was $3 \%$ greater than that in the control cheese (Hassan et al., 2004). This is a major factor responsible for the improvement in the textural characteristics of EPS-positive cheese.

Other Soft Cheeses. A moderately ropy strain of Strep. thermophilus produced Feta cheese with an undesirable slippery texture (A. N. Hassan, unpublished data). Such texture was not produced in the acid-coagulated cheese (Karish) by the same strain. This was because of differences in the characteristics of rennet curd and acid-coagulated curd. Unlike rennet curd, acid curd does not show immediate syneresis after cutting (Lucey, 2002). Once the cheese is cut, a sheet of whey is normally formed on the surface of the rennet-coagulated cheese. Exopolysaccharides are located in the serum phase of the 3-dimensional network of cheese and fermented milks (Hassan et al., 2002b, 2003a,b; Hassan and Awad, 2005). Therefore, the released EPS-containing whey would produce slippery rennet-coagulated cheese. The capsular type of EPS would be recommended for making rennet-coagulated soft cheeses because it does not cause ropiness. The capsular and moderately ropy EPS can be used successfully in making acid-coagulated soft cheese unless the viscosity of the whey is a concern, in which case only the capsular type should be used. Moreira et al. (2003) increased moisture retention and improved meltability, textural, and proteolytic properties of a soft cheese, Quartirolo, by using EPS-producing cultures.

\section{CONCLUSIONS}

Exopolysaccharide-producing cultures can be used to improve the physical properties of dairy products. The selection criteria of such cultures depend on the physical characteristics desired in the product. A trial-anderror approach can be taken when selecting EPS-producing cultures. However, knowledge of the type and structure of EPS, their function-structure relationship, and factors affecting their production and interaction with milk proteins is a key for maintaining success in a highly specialized and rapidly changing dairy market. Solutions of purified dried EPS in water do not always exhibit thickening properties. Therefore, in situ EPS production by lactic acid bacteria has been recommended. However, economically, production of a dried ingredient containing EPS that can recover its original function in solution would be more desirable. In marketing EPS or EPS-producing cultures as an alternative to conventional stabilizers, the cost of production would be a major challenge. The rewarding opportunities to the dairy industry would be possibilities in the organic and functional dairy products markets.

\section{REFERENCES}

Agrawal, P., and A. N. Hassan. 2007. Ultrafiltered milk reduces bitterness in reduced-fat Cheddar cheese made with an exopolysaccharide-producing culture. J. Dairy Sci. 90:3110-3117.

Ahmed, N. H., M. Elsoda, A. N. Hassan, and J. F. Frank. 2004. Improving the textural properties of an acid-coagulated (Karish) cheese using exopolysaccharide producing cultures. LWT-Food Sci. Technol. 38:843-847.

Amatayakul, T., F. Sherkat, and N. P. Shah. 2006. Syneresis in set yogurt as affected by EPS starter cultures and levels of solids. Int. J. Dairy Technol. 59:216-221.

Awad, S., A. N. Hassan, and F. Halaweish. 2005a. Application of exopolysaccharide- producing cultures in reduced fat Cheddar cheese. Composition and proteolysis. J. Dairy Sci. 88:4195-4203.

Awad, S., A. N. Hassan, and K. Muthukumarappan. 2005b. Application of exopolysaccharide-producing cultures in reduced-fat Cheddar cheese. Texture and melting properties. J. Dairy Sci. 88:4204-4213.

Broadbent, J. R., D. J. McMahon, D. L. Welker, C. J. Oberg, and S. Moineau. 2003. Biochemistry, genetics, and applications of exopolysaccharide production in Streptococcus thermophilus: A review. J. Dairy Sci. 86:407-423.

Cerning, J. 1990. Exocellular polysaccharides produced by lactic acid bacteria. FEMS Microbiol. Rev. 87:113-130.

Dabour, N., E. Kheadr, N. Benhamou, I. Fliss, and G. LaPointe. 2006. Improvement of texture and structure of reduced-fat Cheddar cheese by exopolysaccharide-producing lactococci. J. Dairy Sci. 89:95-110.

Dabour, N., E. E. Kheadr, I. Fliss, and G. LaPointe. 2005. Impact of ropy and capsular exopolysaccharide-producing strains of Lactococcus lactis subsp. cremoris on reduced-fat Cheddar cheese production and whey composition. Int. Dairy J. 15:459-471.

De Vuyst, L., F. De Vin, F. Vaningelgem, and B. Degeest. 2001. Recent developments in the biosynthesis and applications of heteropolysaccharides from lactic acid bacteria. Int. Dairy J. 11:687-707.

De Vuyst, L., F. Vanderverken, S. van de Van, and B. Degeest. 1998. Production by and isolation of exopolysaccharides from Streptococcus thermophilus grown in a milk medium and evidence for their growth-associated biosynthesis. J. Appl. Microbiol. 84:1059-1068.

Degeest, B., F. Vaningelgem, and L. De Vuyst. 2001. Microbial physiology, fermentation kinetics, and process engineering of heteropolysaccharide production by lactic acid bacteria. Int. Dairy J. 11:747-757. 
Emmons, D. B., M. Kalab, E. Larmond, and R. J. Lowrie. 1980. Milk gel structure X. Texture and microstructure in Cheddar cheese made from whole milk and from homogenized low fat milk. J. Texture Stud. 11:15-34.

Faber, E. J., P. Zoon, J. P. Kamerling, and J. F. Vliegenthart. 1998. The exopolysaccharides produced by Streptococcus thermophilus Rs and Sts have the same repeating unit but differ in viscosity of their milk cultures. Carbohydr. Res. 310:269-276.

Fenelon, M. A., M. P. Ryan, M. C. Rea, T. P. Guinee, R. P. Ross, C. Hill, and D. Harrington. 1999. Elevated temperature ripening of reduced fat Cheddar made with or without lacticin 3147-producing starter culture. J. Dairy Sci. 82:10-22.

Folkenberg, D. M., P. Dejmek, A. Skriver, H. S. Guldager, and R. Ipsen. 2006. Sensory and rheological screening of exopolysaccharide producing strains of bacterial yoghurt cultures. Int. Dairy J. 16:111-118.

François, Z., N. Ahmed, M. Félicité, and M. Elsoda. 2004. Effect of ropy and capsular exopolysaccharides producing strain of Lactobacillus plantarum 162RM on characteristics and functionality of fermented milk and soft Karish type cheese. Afr. J. Biotechnol. $3: 512-518$.

Gamar-Nourani, L., K. Blondeau, and J.-M. Simonet. 1998. Influence of culture conditions on exopolysaccharide production by Lactobacillus rhamnosus C83. J. Appl. Microbiol. 85:664-672.

Goh, K. T., Y. Hemar, and H. Singh. 2005. Viscometric and static light scattering studies on an exopolysaccharide produced by Lactobacillus delbrueckii subspecies bulgaricus NCFB 2483. Biopolymers 77:98-106.

Gorret, N., J. L. Maubois, J. M. Engasser, and M. Ghoul. 2001. Study of the effects of temperature, $\mathrm{pH}$ and yeast extract on growth and exopolysaccharides production by Propionibacterium acidipropionici on milk microfiltrate using a response surface methodology. J. Appl. Microbiol. 90:788-796.

Grobben, G. J., I. C. Boels, J. Sikkema, M. R. Smith, and J. A. M. De Bont. 2000. Influence of ions on growth and production of exopolysaccharides by Lactobacillus delbrueckii subspecies bulgaricus NCFB 2772. J. Dairy Res. 67:131-135.

Hassan, A. N., and S. Awad. 2005. Application of exopolysaccharideproducing cultures in reduced-fat Cheddar cheese. Cryo-scanning electron microscopy observations. J. Dairy Sci. 88:4214-4220.

Hassan, A. N., S. Awad, and V. V. Mistry. 2007. Reduced fat process cheese made from young reduced fat Cheddar cheese manufactured with exopolysaccharide-producing cultures. J. Dairy Sci. 90:3604-3612.

Hassan, A. N., S. Awad, and K. Muthukumarappan. 2005. Effects of exopolysaccharide- producing cultures on the viscoelastic properties of reduced-fat Cheddar cheese. J. Dairy Sci. 88:4221-4227.

Hassan, A. N., M. Corredig, and J. F. Frank. 2001a. Viscoelastic properties of yogurt made with ropy and nonropy exopolysaccharides producing cultures. Milchwissenschaft 56:684-687.

Hassan, A. N., M. Corredig, and J. F. Frank. 2002a. Capsule formation by nonropy starter cultures affects the viscoelastic properties of yogurt during structure formation. J. Dairy Sci. 85:716-720.

Hassan, A. N., M. Corredig, J. F. Frank, and M. Elsoda. 2004. Microstructure and rheology of an acid-coagulated cheese (Karish) made with an exopolysaccharide-producing Streptococcus thermophilus strain and its exopolysaccharide non-producing genetic variant. J. Dairy Res. 71:116-120.

Hassan, A. N., and J. F. Frank. 2001b. Starter cultures and their use. Pages 151-206 in Applied Dairy Microbiology. 2nd ed. E. H. Marth and J. L. Steele, ed. Marcel Dekker Inc., New York, NY.

Hassan, A. N., J. F. Frank, and M. Elsoda. 2003a. Observation of bacterial exopolysaccharide in dairy products using cryo-scanning electron microscopy. Int. Dairy J. 13:755-762.

Hassan, A. N., J. F. Frank, M. A. Farmer, K. A. Schmidt, and S. I. Shalabi. 1995a. Observation of encapsulated lactic acid bacteria using confocal scanning laser microscopy. J. Dairy Sci. 78:2624-2628.

Hassan, A. N., J. F. Frank, M. A. Farmer, K. A. Schmidt, and S. I. Shalabi. 1995b. Formation of yogurt microstructure and threedimensional visualization as determined by confocal scanning laser microscopy. J. Dairy Sci. 78:2629-2636.
Hassan, A. N., J. F. Frank, and K. B. Qvist. 2002b. Direct observation of bacterial exopolysaccharides in dairy products using confocal scanning laser microscopy. J. Dairy Sci. 85:1705-1708.

Hassan, A. N., J. F. Frank, K. A. Schmidt, and S. I. Shalabi. 1996a. Rheological properties of yogurt made with encapsulated nonropy lactic cultures. J. Dairy Sci. 79:2091-2097.

Hassan, A. N., J. F. Frank, K. A. Schmidt, and S. I. Shalabi. 1996b. Textural properties of yogurt made with encapsulated nonropy lactic cultures. J. Dairy Sci. 79:2098-2103.

Hassan, A. N., J. F. Frank, and S. I. Shalabi. 2001c. Factors affecting capsule size and production by lactic acid bacteria used as dairy starter cultures. Int. J. Food Microbiol. 64:199-203.

Hassan, A. H., R. Ipsen, T. Janzen, and K. B. Qvist. 2003b. Microstructure and rheology of yogurt made with cultures differing only in their ability to produce exopolysaccharides. J. Dairy Sci. 86:1632-1638.

Korakli, M., and R. F. Vogel. 2006. Structure/function relationship of homopolysaccharide producing glycansucrases and therapeutic potential of their synthesized glycans. Appl. Microbiol. Biotechnol. 71:790-803.

Lawrence, R. C., and J. Gilles. 1980. The assessment of potential quality of young Cheddar cheese. N.Z. J. Dairy Sci. Technol. 15:1-12.

Levander, F., and P. Rådström. 2001. Requirement for phosphoglucomutase in exopolysaccharide biosynthesis in glucose- and lactoseutilizing Streptococcus thermophilus. Appl. Environ. Microbiol. 67:2734-2738.

Low, D., J. A. Ahlgren, D. Horne, D. J. McMahon, C. J. Oberg, and J. Broadbent. 1998. Role of Streptococcus thermophilus MR-1C capsular exopolysaccharide in cheese moisture retention. Appl. Environ. Microbiol. 64:2147-2151.

Lucey, J. A. 2002. Formation and physical properties of milk protein gels. J. Dairy Sci. 85:281-294.

Marshall, V. M., and H. L. Rawson. 1999. Effects of exopolysaccharide-producing strains of thermophilic lactic acid bacteria on the texture of stirred yogurt. Int. J. Food Sci. Technol. 34:137-143.

Metzger, L. E., and V. V. Mistry. 1995. A new approach using homogenization of cream in the manufacture of reduced fat Cheddar cheese. 2. Microstructure, fat globule distribution, and free oil. J. Dairy Sci. 78:1883-1895.

Mistry, V. V. 2001. Low fat cheese technology. Int. Dairy J. 11:413-422.

Mistry, V. V., and D. L. Anderson. 1993. Composition and microstructure of commercial full-fat and low-fat cheeses. Food Struct. 12:259-266.

Monsan, P., S. Bozonnet, C. Albenne, G. Joucla, R. Willemot, and M. Remaud-Siméon. 2001. Homopolysaccharides from lactic acid bacteria. Int. Dairy J. 11:675-685.

Moreira, M., A. Bevilacqua, and G. De Antoni. 2003. Manufacture of Quartirolo cheese using exopolysaccharide-producing starter culture. Milchwissenschaft 85:301-304

Mozzi, F., G. Savoy, de Giori, G. Oliver, and G. Font de Valdez. 1995. Exopolysaccharide production by Lactobacillus casei. II. Influence of the carbon source. Milchwissenschaft 50:307-309.

Perry, D. B., D. J. McMahon, and C. J. Oberg. 1998. Manufacture of low fat Mozzarella cheese using exopolysaccharide-producing starter cultures. J. Dairy Sci. 81:563-566.

Petersen, B. L., R. I. Dave, D. J. McMahon, C. J. Oberg, and J. R. Broadbent. 2000. Influence of capsular and ropy exopolysaccharide-producing Streptococcus thermophilus on Mozzarella cheese and cheese whey. J. Dairy Sci. 83:1952-1956.

Ricciardi, A., and F. Clementi. 2000. Exopolysaccharides from lactic acid bacteria: Structure, production and technological applications. Ital. J. Food Sci. 12:23-45.

Ruas-Madiedo, P., and C. G. de los Reyes-Gavilán. 2005. Methods for the screening, isolation, and characterization of exopolysaccharides produced by lactic acid bacteria. J. Dairy Sci. 88:843856

Ruas-Madiedo, P., J. Hugenholtz, and P. Zoon. 2002. An overview of the functionality of exopolysaccharides produced by lactic acid bacteria. Int. Dairy J. 12:163-171. 
Rynne, N. M., T. P. Beresford, A. L. Kelly, M. H. Tunick, E. L. Malin, and T. P. Guinee. 2007. Effect of exopolysaccharide-producing adjunct starter cultures on the manufacture, composition and yield of half-fat Cheddar cheese. Aust. J. Dairy Technol. 62:12-18.

Tamime, A. Y., A. Hassan, E. Farnworth, and T. Toba. 2007. Structure of fermented milks. Pages 134-169 in Structure of Dairy Products. A. Y. Tamime, ed. Blackwell Publ. Ltd., Oxford, UK.

van Marle, M. E., and P. Zoon. 1995. Permeability and rheological properties of microbially and chemically acidified skim milk gels. Neth. Milk Dairy J. 49:47-65.
Welman, A. D., and I. S. Maddox. 2003. Exopolysaccharides from lactic acid bacteria: Perspective and challenges. Trends Biotechnol. 21:269-274.

Zisu, B., and N. P. Shah. 2003. Effects of pH, temperature, supplementation with whey protein concentrate, and adjunct cultures on the production of exopolysaccharides by Streptococcus thermophilus 1275. J. Dairy Sci. 86:3405-3415.

Zisu, B., and N. P. Shah. 2004. Low-fat Mozzarella as influenced by microbial exopolysaccharides, preacidification and whey protein concentrate. J. Dairy Sci. 88:1973-1985. 